\title{
ÚČAST ČESKOSLOVENSKA NA ZŘíZENÍ SPOJENÉHO ÚSTAVU JADERNÝCH VÝZKUMŮ (DUBNA, RUSKO) A ZASTOUPENÍ V JEHO PRVNÍM ŘEDITELSTVÍ
}

\author{
EMILIE TĚŠÍNSKÁ
}

\author{
Motto: \\ „A posledni prosba. Neposílejte nám, pokud to je možné, \\ tajné spisy a neoznačujte doma za tajné naše spisy, \\ které jsme tak my sami neoznačili.“”
}

[V. Votruba, na závěr dopisu J. Kožešníkovi, Dubna 21. února 1957]

\section{PARTICIPATION OF CZECHOSLOVAKIA IN THE ESTABLISHMENT OF THE JOINT INSTITUTE FOR NUCLEAR RESEARCH (DUBNA, RUSSIA) AND ITS REPRESENTATION IN THE INSTITUTE'S FIRST DIRECTORATE}

\begin{abstract}
Within a wider context of the starting international collaboration in nuclear physics and peaceful uses of nuclear energy in the 1950s, this article outlines Czechoslovak participation in the establishement of the Joint Institute for Nuclear Research (JINR) in Dubna (Russia) in 1956. The Institute was intended to serve as a parallel to the European Laboratory for Nuclear Research (CERN) for countries of the Eastern Bloc. The article includes a 'memory record' describing how Czechoslovakia was in January 1956 invited to participate in the creation of the Institute. Next, the article outlines the composition and contributions of the Czechoslovak delegation at a meeting of eleven founding states in Moscow in March 1956 and investigates the circumstances of election of Václav Votruba (1909-1990), a Czechoslovak theoretical physicist, to the post of Vice-Director of the Institute and his subsequent activities in this function in 1955-1959. The article also describes a visit of the Institute by a Czechoslovak governmental and Communist Party delegation headed by President Antonín Zápotocký in January 1957 and subsequent pardon, which the President granted to V. Votruba's PhD student and collaborator Miloš Lokajiček (1923-2019), who was in 1954 sentenced to seven years in prison for participation in a Catholic association called 'The Family'.
\end{abstract}

Keywords: international scientific collaboration - Joint Institute for Nuclear Research in Dubna - Czechoslovak nuclear and particle physics - 1950s - Václav Votruba (1909-1990)

DOI: $10.14712 / 23365730.2021 .3$

Československo bylo jednou z jedenácti signatářských zemí Dohody o zrŕzení Spojeného ústavu jaderných výzkumů, která byla podepsána 26. března 1956 v Moskvě. Československý teoretický fyzik Václav Votruba (1909-1990) byl zvolen jedním z prvních dvou náměstků prvního ředitele Spojeného ústavu jaderných výzkumů D. I. Blochinceva; tento post zastával do března 1959. V př́spěvku je uveden širší historický kontext zmíněných událostí podle písemných pramenů nalezených $\mathrm{v}$ archivech. Napsání př́spěvku bylo motivováno 65. výročím založení Spojeného ústavu jaderných výzkumů (v roce 2021) a připomenutím osobnosti Václava Votruby (od jehož narození uplynulo v roce 2020 již 110 let). 


\section{1. Úvod}

Zřízení Spojeného ústavu jaderných výzkumů (SÚJV) v roce 1956 bylo na jedné straně součástí úsilí vědců o mezinárodní spolupráci v oblasti výzkumů a mírového využití atomové energie, na druhé straně důsledkem poválečného geopoliticky polarizovaného světa. Odvíjelo se v kontextu řady dalších relevantních událostí na poli mezinárodní politiky, diplomacie a vědecké spolupráce: zrrízení a budování Evropské laboratoře jaderných výzkumů CERN, příprava a konání První mezinárodní konference o mírovém využití atomové energie, nabídka a konkretizace dvoustranných mezivládních dohod o sovětské vědecko-technické pomoci Československu, Číně, Mad’arsku, NDR, Polsku a Rumunsku při budování středisek pro jaderný výzkum a využití jaderné energie, zasedání Vědeckého výboru OSN pro zkoumání účinkủ atomového záření (UNSCEAR), diplomatická a vědecko-technická jednání jaderných mocností o zákazu a kontrole zkoušek jaderných zbraní, př́ípravná jednání o Mezinárodní agentuře pro atomovou energii (IAEA) apod.

O československé účasti na zřízení (budoucího) SÚJV v Sovětském svazu se rozhodovalo primárně na úrovni ústředních orgánů KSČ a tehdejš́ho Vládního výboru pro mírové využití atomové energie (VVAE) při předsednictvu vlády. ${ }^{1}$ Po podpisu mezivládní Dohody o zř́zení SÚJV a po zrušení VVAE byla agendou československé spolupráce s SÚJV vládou pověřena Československá akademie věd (ČSAV). Prostředníkem v počáteční komunikaci o SÚJV bylo československé velvyslanectví v Moskvě.

Př́iznačným rysem doby bylo, že i jednání o spolupráci deklarované jako výzkum a mírové využití jaderné energie byla většinou klasifikována jako „tajná“ nebo dokonce „přísně tajná“. U dokumentů v českých a slovenských archivech byl dobový stupeň utajení již zrušen, jsou však rozptýleny v různých fondech a jsou jen zlomkovité. $Z$ ruských archivů je zatím dostupná pouze část relevantních dokumentů z 50. let 20. století. Postihnout všechny dobové souvislosti československé účasti na zřízení Spojeného ústavu jaderných výzkumů je proto úkol pro dlouhodobější a mezioborové bádání; důležité jsou při tom také historické paralely účasti jiných zemí na zř́zení Spojeného ústavu jaderných výzkumů a navazování spolupráce s CERN. ${ }^{2}$

1 Vládní výbor pro výzkum a mírové využití atomové energie (VVAE) byl oficiálně zřízen vládním nařízením č. 30 z 10. června 1955, konstituoval se však již usnesením Politického byra ÚV KSČ koncem února 1955. Zřízení tohoto orgánu souviselo jednak s přípravou československé účasti na První mezinárodní konferenci o mírovém využití atomové energie (o jejímž uspořádání bylo rozhodnuto rezolucí č. 810 přijatou usnesením IX. Valného shromáždění OSN 4. prosince 1954), jednak s nabídkou vědecko-technické pomoci při budování středisek pro výzkum a mírové využití atomové energie, která byla učiněna vládou SSSR vládě ČSR počátkem roku 1955. Vládním usnesením č. 19 z 16. června 1956 byl však VVAE zrušen a jeho kompetence (s výjimkou řízení jemu podřízeného Ústavu jaderné fyziky, který byl začleněn do ČSAV) převedeny na ministerstvo energetiky. K tomu podrobněji např. Emilie TĚŠínSKÁ, Z historie Ústavu jaderné fyziky AV ČR, in: Ústav jaderné fyziky AV ČR - 50 let - Řež 1955-2005, Řež 2005, s. 7-65.

2 K historii CERN i SÚJV existuje poměrně bohatá historiografická literatura. Historické paralely účasti jednotlivých zemí v těchto mezinárodních vědeckých centrech však většinou chybí. Srov. E. TĚŠínskÁ (ed.), Mezi SÚJV a CERN. Pamětnická ohlédnutí za českou a slovenskou spoluprací se Spojeným ústavem jaderných výzkumů Dubna (SÚJV) a Evropskou organizaci pro jaderný výzkum (CERN), Praha 2019, s. 7-13 (Úvodní slovo editorky, odkazy v poznámkách pod čarou). 


\section{Přizvání Československa $\mathrm{k}$ účasti na zřízení Východního ústavu jaderných výzkumů jako paralely CERN}

Československo bylo přizváno k účasti na založení Východního ústavu jaderných výzkumů, který se měl stát paralelou Evropské laboratoře jaderných výzkumů CERN pro země lidové demokracie, dopisem („,pamětním záznamem“) z 18. ledna 1956 zaslaným prvním tajemníkem Ústředního výboru KSSS N. S. Chruščovem prvnímu tajemníkovi Ústředního výboru KSČ Antonínu Novotnému. Text dopisu (v dobovém českém překladu) byl následující:

\section{„Pamètní záznam.}

$V$ době konání ženevské konference vyvstala u některých vědců ze zemí lidové demokracie otázka účelnosti toho, aby země lidové demokracie vstoupily do evropské laboratoře pro atomovou energii.

Evropská laboratoŕ pro atomovou energii má sídlo v Ženevě. Do značné míry byla organizována z iniciativy USA. V práci se zde účastni: Anglie, Francie, Západní Německo, Itálie, Belgie, Holandsko, Švédsko, Norsko, Dánsko, Švýcarsko, Jugoslávie a Řecko.

V roce 1955 se organisátoři této laboratoře usnesli zastavit do 1. ledna 1957 príijímání nových členských států do laboratoře.

Tímto usnesením se pravděpodobně sleduje, aby dveře laboratoře byly uzavřeny pro zemé lidové demokracie.

ÚV KSSS je toho názoru, že pro socialistické země nemá smyslu vstupovat do evropské laboratoře. Poněvadž tato laborator je umistěna ve Švýcarsku a také proto, že se nacházi pod kontrolou USA, nebyly by zde vhodné podminky pro práci védcu našich zemí a v prípadě, že by nastaly některé neprìznivé změny v mezinárodní politice, mohlo by se stát, že pro naše vědce by se tam práce stala vi̊bec nemožnou.

Kromě jiného jsou na členech laboratoře požadovány velké náklady na vydržováni a na výstavbu nových fysikálnich př́stroju․ Tyto náklady by se mohly ukázat zbytečnými.

Jsme toho názoru, že zemé lidové demokracie, Činská lidová republika, Korejská lidové demokratická republika, Mongolská lidová republika a SSSR by měly organisovat své východni středisko jaderného bádání, jež by bylo pro výzkum v oblasti atomového jádra vybaveno nejmodernéjším zařizením.

Vytvořením východniho střediska pro jaderná bádáni dostanou členské státy možnost provádèt pokusná vědecká bádáni v oblasti využití atomové energie na vysoké úrovni.

Pokud jde o evropskou laborator̆, pak nutný vědecký kontakt s ní bude možno udržovat, bude-li k tomu přiznivá situace, pomocí výměny pracovnikư a výměny dosažených úspěchü, ziskaných v oblasti bádání.

Otázku vytvoření východního střediska jaderného bádání by bylo účelné projednat na konferenci zástupců zainteresovaných zemí.

Jsme toho názoru, že na této konferenci by mély být projednány tyto otázky:

1) misto, kde má být umistěn ústav,

2) výstavba pokusných zařizení ústavu,

3) príspěvky členů ústavu na jeho výstavbu a vydržování,

4) pozvání Indie a jiných zemí,

5) organisace vedení ústavu. 
Jestliže se ukáže účelným umístit ústav v SSSR, pak ÚV KSSS pokládá za možné dát mu $k$ disposici ústav jaderných problémů, nacházející se v obvodu Moskvy, kde je již v chodu velký cyklotron, umožňující získávat protony s energii 580 milionů elektr. woltů (!), a v tomtéž obvodu již vybudovaný kruhový zrychlovač s energii protonů 10 miliard elektr. woltů (!).

Tyto zrychlovače jsou největši na světě. Zatím co evropská laboratoř se teprve buduje a jeji zrychlovače mohou být uvedeny do chodu teprve za několik let, východní ústav, bude-li umístěn v uvedeném již do provozu ústavu jaderných problémů, může ihned dát vědcům našich zemi dobré podmínky pro produktivní práci.

Podle našeho názoru bude třeba v nejbližšich 2-3 letech vybudovat ještě jeden zrychlovač vícenábojových (víceštěpných: pozn. překl.) iontů, atomový kotel s velkou hustotou neutronü, laboratorni mistnosti a potřebný počet ubytoven.

ÚV KSSS vás prosí, abyste posoudili účelnost výstavby východního ústavu pro jaderná bádání a sdělili nám váš názor.

18. ledna 1956"3

Dopis byl projednán ve schůzi Politického byra Ústředního výboru KSČ (PB ÚV KSČ) 23. ledna 1956. V přijatém usnesení byl sovětský návrh na vybudování Východního ústavu jaderných výzkumů uvítán, byl vysloven souhlas s umístěním ústavu v Sovětském svazu a s konáním porady zástupců oslovených zemí v Moskvě. Náměstkovi předsedy vlády Václavu Kopeckému, který byl zároveň předsedou československého Vládního výboru pro výzkum a mírové využití atomové energie (VVAE), bylo uloženo, aby zajistil a předložil PB ÚV KSČ ke schválení československé stanovisko k nastoleným otázkám a návrh na složení československé delegace na poradu v Moskvě. ${ }^{4}$

\section{Historický kontext sovětského návrhu}

Sovětský návrh na zřízení Východního ústavu jaderných výzkumů byl reakcí a odpovědí na neformální jednání o spolupráci ve fyzice vysokých energií na První mezinárodní konferenci o mírovém využití atomové energie v Ženevě v srpnu 1955 (dále též zkráceně ženevská konference), během nichž byla nastolena a diskutována otázka spolupráce ve fyzice vysokých energií a vstupu zemí východní Evropy do CERN. ${ }^{5}$

3 Národní archiv Praha (dále NA), fond PB ÚV KSČ 1954-1962, i. č. 99, a. j. 81, schůze 23. 1. 1956, bod 8.

4 Tamtéž, bod 28.

5 Ke vstupu do CERN bylo během ženevské konference při neformálních rozhovorech vyzváno Polsko; na polského delegáta P. Szulkina (profesora Varšavské polytechniky a člena korespondenta Polské akademie věd) se v této věci údajně obrátili někteři vědci Francie, Itálie a Jugoslávie. Zároveň na neformálním setkání členů delegací (fyziků) Polska, Československa a Mad'arska během konference zazněly návrhy na zř́zení východní laboratoře jaderných výzkumů. Б. М. СТАРЧЕНКО - Ю. Г. ШИМАНСКАЯ - И. Ю. ЩЕРБАКОВА (eds.), История создания ОИЯИ в решениях ЦК КПСС 1955-1958, Дубна 2015, s. 14. O neformálních jednáních během ženevské konference se zmiňuje také profesor Č. Šimáně ve svých pamětech. Uvádí, že během ženevské konference se sešlo několik účastníků ze zemí východní Evropy na společném obědě. Přítomni byli mj. L. Infeld a M. Danysz z Polska, L. Jánossy z Mad’arska, G. Nadžakov z Bulharska a H. Hulubei z Rumunska, V. Votruba a Č. Šimáně z Československa. Oběda se účastnil i zástupce východního Německa, které nebylo oficiálním účastnickým státem konference. „Když se začalo hovořit o výzkumu v oblasti fyziky vysokých energií, tedy oblasti, pro kterou byl už na Západě založen CERN v Ženevě, zjistilo se, že pro tuto oblast fyziky není v našich zemích perspektiva, protože Sovětský svaz nenabídl žádný větší urychlovač. Debata dospěla k názoru, že by bylo žádoucí, sami se začít zabývat stavbou takového urychlovače. $V$ té době byl už znám princip tak zvané 
Sovětské stanovisko k této otázce a koncept dopisu o zřízení Východního ústavu jaderných výzkumů připravilo Ministerstvo středního strojírenství SSSR. Pod konceptem datovaným 4. listopadu 1955 byli podepsáni náměstek ministra B. Vannikov a vedoucí fyzik sovětského jaderného programu I. V. Kurčatov. Podle původního návrhu měl být dopis zaslán generálním tajemníkům ústředních výborů vedoucích politických stran Polska, Československa, NDR, Mad'arska, Bulharska a Rumunska (uvedeno v tomto pořadí); Čínská lidová republika, Korejská lidově-demokratická republika, popř. další asijské země měly být osloveny až později. Jako nejvhodnější místo pro konání porady o zřízení ústavu byl původně navržen Kyjev nebo Praha, datum konání porady předběžně stanoveno na leden 1956.

V konečném znění dopisu, které bylo schváleno Prezídiem ÚV KSSS 14. ledna 1956, nebylo místo a datum konání porady (konference) o zrrízení Východního ústavu jaderných výzkumů specifikováno, byla však do něho již vtělena nabídka na zř́zení ústavu v Sovětském svazu na bázi dvou velkých urychlovačů v ústavech AV SSSR. Dopis byl souběžně zaslán i stranickým představitelům ČLR, KLDR, Mongolské lidové republiky a Albánské lidové republiky. Zvláštním dopisem ze 14. ledna 1956 byla účast ve Východním ústavu jaderných výzkumů nabídnuta také Jugoslávii, která již byla členem CERN. ${ }^{6}$

\section{4. Československá účast na ženevské konferenci a předchozí setkání s budoucí Dubnou}

První mezinárodní konference o mírovém využití atomové energie, která se konala v Ženevě ve dnech 8.-20. srpna 1955 pod záštitou OSN, se z Československa zúčastnila 17 členná delegace vedená hlavním vědeckým sekretářem ČSAV (a členem VVAE) akademikem Františkem Šormem. Členy delegace byli mj. Čestmír Šimáně (ředitel krátce před tím zřízeného Ústavu jaderné fyziky, který byl podřízen VVAE) a Václav Votruba (člen korespondent ČSAV a profesor teoretické fyziky na Matematicko-fyzikální fakultě Univerzity Karlovy). Jako pracovník vědeckého sekretariátu konference se jí účastnil také Ivan Úlehla (v té době vědecký pracovník teoretického oddělení Ústavu jaderné fyziky). ${ }^{7}$

Početnou delegaci Sovětského svazu na konferenci vedl akademik D. V. Skobel'cyn, jejími členy byli mj. V. S. Jemeljanov (náměstek ministra středního strojírenství SSSR, v letech 1957-1960 pak vedoucí Hlavní správy pro využití atomové energie při Radě ministrů SSSR), A. V. Topčijev (hlavní sekretář prezídia AV SSSR), D. I. Blochincev (ředitel první sovětské jaderné elektrárny) a V. I. Veksler (ředitel Elektrofyzikální laboratoře AV

silné fokusace, který umožňoval stavbu urychlovačů na vysoké energie, nepoměrně lehčích než urychlovače, které byly stavěny klasickým způsobem. Protože jsem věděl, že ve Výzkumném ústavu vakuové techniky v Praze v Hloubětíně existuje skupina vedená Dr. Seidlem, jejímiž členy byli také L. Šípek a J. Teichman, která by mohla předložit návrh elektronového synchrotronu na tomto principu, prohlásil jsem nezávazně, že bychom se o projekt takového urychlovače mohli pokusit. Rovněž mad’arský představitel něco podobného navrhoval.“ “ Čstmír ŠImÁNĚ, Život mezi atomy aneb jak to vše u nás i jinde začínalo, Ústav jaderného výzkumu Řež a. s. 2005, s. 249-250. K tomu viz též dále oddíl 5 a 6.

6 Б. М. СТАРЧЕНКО - Ю. Г. ШИМАНСКАЯ - И. Ю. ЩЕРБАКОВА (eds.), История созданИЯ ОИЯИ, s. 14-22.

7 O složení československé delegace na První mezinárodní konferenci o mírovém využití atomové energie bylo rozhodnuto usnesením vlády č. 1855 z 13. července 1955. 
SSSR a autor principu synchrotronu, který formuloval nezávisle na americkém fyzikovi E. McMillanovi).

Na konferenci zazněla řada přednášek o urychlovačích a fyzice částic vysokých energií. V. I. Veksler se $\mathrm{v}$ přednášce o principech urychlování nabitých částic, kterou přednesl na jednom z večerních zasedání konference, zmínil také o sovětském „fázotronu“ (synchrocyklotronu) pro energie $580 \mathrm{MeV}$ a dokončovaném „synchrofázotronu“ pro energie $10 \mathrm{GeV}$, ovšem bez uvedení lokace těchto zařízení. ${ }^{8}$ Tyto urychlovače byly půl roku poté $\mathrm{v}$,,pamětním záznamu“ ÚV KSSS nabídnuty jako výchozí experimentální zařízení pro Východní ústav jaderných výzkumů.

Informace o největších sovětských urychlovačích ovšem nebyla pro zahraniční odborníky již novinkou. Někteří měli př́ležitost je osobně zhlédnout (přinejmenším již provozovaný synchrocyklotron) necelé dva měsíce před ženevskou konferencí, během jedné z exkursí uspořádaných pro zahraniční hosty (veřejného) zasedání AV SSSR o mírovém využití atomové energie, které se konalo ve dnech 1.-5. července 1955 v Moskvě. Z Československa se tohoto zasedání a exkursí zúčastnila delegace, kterou tvořili V. Votruba a tři pracovníci Ústavu jaderné fyziky (ÚJF): ředitel Č. Šimáně, jeho náměstek Jan Urbanec a vedoucí sektoru radiochemie Jaromír Malý. O zasedání a zhlédnutých jaderných zařízeních během exkursí (včetně návštěvy první sovětské jaderné elektrárny) referovali mj. v článku uveřejněném 31. července 1955 v Rudém právu. ${ }^{9}$

O vybudování urychlovače, který by sloužil základnímu výzkumu ve fyzice vysokých energií, se uvažovalo také v Československu. Projekt elektronového synchrotronu se silnou fokusací pro energie $1 \mathrm{GeV}$ byl vypracován v oddělení kruhových urychlovačů Výzkumného ústavu pro vakuovou elektrotechniku (VÚVET) ministerstva (přesného) strojírenství pod vedením inženýrů Jana Váni a Miloše Seidla. ${ }^{10}$ Koncem roku 1955, u př́ležitosti jednání Č. Šimáně a Ladislava Trlifaje (vedoucího teoretického oddělení ÚJF) v Moskvě o konkretizaci sovětské nabídky na školení československých odborníků v jaderných oborech v Sovětském svazu, byl již téměř hotový projekt tohoto urychlovače předložen ke konzultaci sovětským odborníkům jako návrh experimentálního zařízení, které by mohlo sloužit spolupráci zemí východní Evropy ve fyzice vysokých energií. Po rozhodnutí o zřízení Spojeného ústavu jaderných výzkumů v Sovětském svazu, $\mathrm{k}$ němuž došlo vzápětí, však bylo od stavby tohoto zařízení v Československu upuštěno. ${ }^{11}$

8 В. И. Векслер, Принциипы ускорения заряженных частиц, in: Мирное исспользование атомной энергии. Материалы Международной Конференции в Женеве, август 1955, т. 16, Москва 1958, s. 82-87.

9 Podrobněji E. Těšínská, K počátkům mezinárodni spolupráce v oblasti mírového využiti atomové energie, Bezpečnost jaderné energie 26 (64), 2018, s. 88-103.

10 První synchrotron se silnou fokusací, elektronový synchrotron na energii $1 \mathrm{GeV}$, postavil R. Wilson v roce 1954 na Cornellově univerzitě v USA. Zmiňují se o tom také Č. ŠıMÁNĚ a M. SEIDL v jejich monografii Urychlovače iontů a elektronů, SNTL Praha 1959, s. 187, a to s odkazem na přednášku R. Wilsona na konferenci o fyzice vysokých energií v Moskvě v létě 1956 . V knize publikovali také fotografii tohoto urychlovače.

11 NA, fond PB UV KSČ 1954-1962, i. č. 85, a. j. 69, schůze 21. 10. 1955, bod 24. Srov. též poznámku č. 5. 


\section{Dohoda o spolupráci ve výzkumu kosmického záření uzavřená na ženevské konferenci}

Jedním z výsledků První ženevské konference o mírovém využití atomové energie byla dohoda o účasti zemí východní Evropy na mezinárodním projektu výzkumu kosmického záření. Šlo o účast na prohlížení a vyhodnocení interakcí kosmického záření s atomovými jádry fotografických emulsí ozářených ve stratosféře během tzv. Pádské expedice, která byla organizována britským fyzikem, laureátem Nobelovy ceny C. F. Powellem. Dohoda byla uzavřena na soukromé schůzce představitelů pěti laboratoří zabývajících se výzkumem kosmického záření a elementárních částic v Československu, Mad’arsku, NDR, Polsku a SSSR dne 19. srpna 1955. Za Československo se schůzky zúčastnil a dohodu podepsal V. Votruba, za Mad’arsko L. Jánossy, za NDR A. Büchner, za Polsko M. Danysz a za SSSR N. A. Dobrotin. Na základě konzultace $\mathrm{s}$ vedoucími národních delegací byla stanovena maximální možná výše finančního př́spěvku jednotlivých účastníků dohody na zmíněnou expedici (resp. na zakoupení ozářených desek): 1500 liber ČSR, 500 liber Mad’arsko, 1000 liber Polsko; výše př́spěvku NDR a SSSR měla být stanovena dodatečně.

Spolupráce československých, polských a mad’arských fyziků byla poté konkretizována na první pracovní konferenci ve Varšavě 4. listopadu 1955. Za Československo se konference zúčastnili Jaroslav Pernegr (vedoucí skupiny studia kosmického záření metodou nukleárních emulsí ve Fyzikálním ústavu ČSAV v Praze) a Juraj Dubinský z Košic (za budovanou vysokohorskou laboratoř kosmického záření na Lomnickém štítu). ${ }^{12}$ Nejintenzivněji se v rámci dohody rozvinula československo-polská spolupráce. Z Pádské expedice byly získány ozářené fotoemulse, $v$ nichž byly československou skupinou nalezeny jaderné interakce s tehdy nejvyšší zaznamenanou energií řádově $10^{14} \mathrm{eV} /$ nukleon. J. Pernegr v rámci této spolupráce navrhl a spolu s polskými fyziky rozpracoval tzv. dvoucentrový model interakcí elementárních částic (publikováno v roce 1958). Souběžně probíhala spolupráce na hyperfragmentech, které objevili J. Pniewski a M. Danysz. Na československo-polskou spolupráci navazovala spolupráce československé skupiny s fyziky v Mad’arsku (např. společná práce o elektron-fotonových kaskádách) a s fyziky v NDR. ${ }^{13}$ Výzkum kosmického záření se stal součástí také širší mezinárodní spolupráce v rámci Mezinárodního geofyzikálního roku, který zahrnul období od 1. července 1957 do 31. prosince 1958.

12 Masarykův ústav a Archiv AV ČR (dále MÚA), fond Sbírka cestovních zpráv pracovníků ČSAV, Polsko 1954, k. 173. J. Pernegr, Zpráva o studijním pobytu v Polsku od 6. ř́ijna - 17. listopadu 1955 (včetně př́íloh).

13 Tehdejší externí vedoucí skupiny kosmického záření ve Fyzikálním ústavu ČSAV Václav Petržílka (profesor a děkan Fakulty technické a jaderné fyziky UK, člen korespondent ČSAV) ve zprávě předložené ve schůzi I. matematicko-fyzikální sekce ČSAV 10. prosince 1955 uvedl, že ČSAV povolila částku 4000 liber na nákup nezbytných př́strojů a materiálu pro realizaci zmíněné mezinárodní spolupráce. Z Milána byly objednány mikroskopy Koristka M.S. 2 s př́íslušenstvím a koncem listopadu 1955 bylo do Československa dodáno 45 vyvolaných speciálních desek s nukleární emulsí, které byly ozářeny kosmickým zářením ve stratosféře během expedice na Sardinii. Desky byly předběžně prohlédnuty skupinou pracovníků z univerzity v Padově a mělo se na nich začít s pozorováním a proměřováním tzv. nestabilních hyperfragmentů. Vedle toho měl být na přelomu roku 1955/56 do Československa dodán další velký počet vyvolaných desek (v hodnotě 1500 liber) z expedice v Pádském údolí. V. Petržílka proto žádal o personální posílení skupiny kosmického záření ve Fyzikálním ústavu ČSAV v roce 1956. Jeho požadavku však tehdy nebylo vyhověno. MÚA, fond I. sekce ČSAV 1952-1961, k. 1, i. č. 20, Fyzikální ústav. Srov. též Václav PETRŽílKA, Třicet let čs. experimentální fysiky elementárních částic, Čs. časopis pro fyziku A 22, 1975, s. 426-428. 


\section{Složení československé delegace a směrnice pro její postup na poradě o Východním ústavu jaderných problémů v Moskvě}

VVAE navrhl, aby na poradu o organizaci Východního ústavu jaderných výzkumů do Moskvy (dále zkráceně moskevská porada) byla vyslána československá delegace ve složení: Jiř́i Baier (stálý úřadující místopředseda VVAE, vedoucí delegace), ${ }^{14}$ Č. Šimáně (ředitel ÚJF a člen VVAE), J. Váňa (ředitel VÚVET) a jako experti L. Trlifaj (vedoucí teoretického oddělení ÚJF) a M. Seidl (vedoucí oddělení urychlovačů VÚVET). Návrh byl schválen ve schůzi PB ÚV KSČ 9. února 1956. ${ }^{15}$

Dopisem ÚV KSSS z 6. března 1956, adresovaným opět A. Novotnému, bylo upřesněno, že porada se bude konat od 20. března a bude na ní podepsána dohoda o zř́zení ústavu zplnomocněnými představiteli vlád zúčastněných zemí. To si vyžádalo změnu ve složení československé delegace. Usnesením PB ÚV KSČ z 12. března 1956 byl vedoucím delegace jmenován ministr energetiky František Vlasák ${ }^{16}$ a J. Baier jmenován jeho zástupcem. Členem delegace zůstal Č. Šimáně, nově navrženými členy byli Václav Petržílka (člen korespondent ČSAV, profesor a děkan v srpnu 1955 zř́zené Fakulty technické a jaderné fyziky UK) a František Kováŕ (od roku 1955 rada československého velvyslanectví v Moskvě pro otázky jaderné energie). Jako experti byli na zasedání vysláni L. Trlifaj, J. Váňa a M. Seidl. ${ }^{17}$ Václav Votruba členem delegace jmenován nebyl. V době konání porady byl služebně v Bulharsku, v Sofii.

Směrnice pro postup československé delegace na poradě byly vypracovány Vědeckou radou ÚJF a 13. března 1956 schváleny VVAE. ${ }^{18}$ Československá delegace měla na poradě mj. navrhnout ( $\mathrm{k}$ bodu 2 nastolenému v pamětním záznamu) vybudování urychlovače protonů pro energie vyšší než $50 \mathrm{GeV}$ a urychlovače elektronů pro energie několika GeV. Ve zprávě F. Vlasáka o účasti československé delegace na poradě však bylo konstatováno, že tyto návrhy nebyly na poradě uplatněny, protože sovětskou delegací byla již navržena výstavba nových zařízení ústavu pro nejbližší tři až čtyři roky „,a jevilo se také správnějším“, aby tyto otázky posoudila až budoucí Vědecká rada ústavu. ${ }^{19}$

14 Jiří Baier (nar. 1915) vystudoval ČVUT v Praze (1938 titul inženýr). V padesátých letech byl poslancem Národního shromáždění RČS za KSČ, volební obvod Praha-město (funkční období od 28. 11. 1954 do 11. 6. 1960, člen rozpočtového a hospodářského výboru). Před tím byl hlavní inženýr ČKD Stalingrad, laureát státní ceny. Později generální ředitel Českých energetických závodủ. Po srpnu 1968 byl v KSČ zařazen na seznam ,představitelů a exponentů pravice“. Viz: <https://cs.wikipedia.org/wiki/Jiř́_Baier_(politik)> (ověřeno 4. 3. 2021).

15 NA, fond PB ÚV KSČ, 1954-1962, i. č. 101, a. j. 107, schůze 9. 2. 1956, usnesení k bodu 28.

16 František Vlasák (1912-2005) vystudoval chemii na Př́rodovědecké fakultě UK (1938 titul RNDr.). Ve vedoucích funkcích státní správy působil od 50. let: 1951-1952 náměstek předsedy Ústředí výzkumu a technického rozvoje, 1953-1955 náměstek ministra - předsedy Státního úřadu plánovacího a od května 1955 do ledna 1958 ministr energetiky. V dalších letech ministr dopravy (leden 1958-leden 1963), ministr - předseda Státní komise pro techniku (zárí 1963-duben 1968), ministr-předseda Státní plánovací komise / ministr plánování (duben 1968-zář́ 1969). Byl členem Ústředního výboru KSČ; po srpnu 1968 v KSČ zařazen na seznam „představitelů a exponentů pravice“" a v roce 1970 z KSČ vyloučen. Do vrcholné politiky se vrátil v únoru 1990 jako místopředseda vlády ČR (funkci zastával do června 1992). Viz: <https://cs.wikipedia.org/wiki/František_Vlasák> (ověřeno 4. 3. 2021).

17 NA, fond PB ÚV KSČ 1954-1962, i. č. 107, a. j. 89, schůze 12. 3. 1956, bod 32.

18 NA, fond Úřad předsednictva vlády (dále ÚPV), usnesení vlády RČS č. 2038 z 9. srpna 1956. Př́iloha č. 3: Zpráva o činnosti čs. delegace na Mezinárodní konferenci o zř́zení Spojeného ústavu pro jaderný výzkum v Moskvě.

19 Tamtéž, s. 5. 


\section{Průběh moskevské porady}

Mezinárodní porada (konference) o Východním ústavu jaderných výzkumů se konala v Moskvě ve dnech 20.-26. března 1956. Zúčastnily se jí vládní delegace 11 zemí tzv. lidové demokracie (Albánské lidové republiky, BLR, ČLR, ČSR, KLDR, MLR, Mongolské lidové republiky, NDR, PLR, RLR a SSSR). Nejpočetnější - osmičlenné - byly delegace ČSR a NDR; v delegaci NDR však tento počet zahrnoval i dva tlumočníky a dva tajemníky. Vedoucím sovětské delegace byl hlavní vědecký tajemník prezídia AV SSSR A. V. Topčijev (jmenovaný a zmocněný k podpisu závěrečné dohody místo náhle onemocnělého prezidenta AV SSSR A. N. Něsmejanova), členy delegace byli dále S. K. Carapkin (člen kolegia Ministra zahraničních věcí SSSR) a fyzici D. I. Blochincev (ředitel první sovětské jaderné elektrárny), V. I. Veksler (ředitel Elektrofyzikální laboratoře AV SSSR) a M. G. Meščerjakov (ředitel Ústavu jaderných problémů AV SSSR).

Porada byla zahájena v kongresovém sále prezídia AV SSSR. Úvodní slovo přednesl A. V. Topčijev. Na návrh československé delegace přednesený J. Baierem byl Topčijev zvolen předsedou prvního zasedání konference. $\mathrm{V}$ dalších zasedáních se $\mathrm{v}$ předsednictví stř́dali představitelé delegací zúčastněných zemí, v pořadí podle ruské abecedy.

$\mathrm{V}$ dopoledním zasedání 20 . března byly předneseny referáty Blochinceva „O umístění Východního ústavu jaderných výzkumů a výstavbě experimentálních zařízení ústavu“ “20 Carapkina „O finančních př́spěvcích členů Východního ústavu jaderných výzkumů na jeho výstavbu a chod“21 a Topčijeva „O organizaci a vedení Východního ústavu jaderných výzkumư“. Byl také rozdán návrh znění závěrečné Dohody. V dalších zasedáních proběhla diskuse $\mathrm{k}$ sovětským návrhům. Na programu 21. března byla celodenní návštěva Ústavu jaderných problémů AV SSSR a Elektrofyzikální laboratoře AV SSSR, 23. března byl volný den a na 26. března byl stanoven podpis závěrečné Dohody. ${ }^{22}$

20 D. I. Blochincev v referátu konkretizoval nabídku Sovětského svazu vybudovat Východní ústav jaderných problémů na bázi dvou již existujících ústavů AV SSSR, s jejich velkými urychlovači a personálem, v městečku v Kalininské oblasti na břehu Volhy. Předložil také sovětský návrh na dobudování ústavu v nejbližších letech, který zahrnoval: stavbu urychlovače vícenábojových iontů pro energie vyšší než 6-7 MeV/nukleon, vybudování laboratoře pro teoretickou fyziku s výpočetním oddělením vybaveným elektronickými počítacími stroji a vybudování laboratoře pro neutronovou fyziku s jaderným reaktorem o vysokém toku neutronů a s horkou chemickou laboratoří. Archiv Spojeného ústavu jaderných výzkumů Dubna (dále Archiv SÚJV), fond 3, opus 1, inventární jednotka 1 (dále citováno jako fond 3/1/1): Материалы международного совещания по вопросу об организации Объединенного института ядерных исследований, dokument „MC [Материалы Совещания] $/ 56 / 5^{“}$.

21 Podílné členské př́íspěvky na dobudování a financování ústavu byly navrženy s ohledem na ekonomické možnosti členských zemí. Největší podíl na sebe vzal SSSR (47,25 \%). Př́ispěvek ČLR byl původně navržen ve výši $10 \%$, čínská delegace na konferenci však (jako jediná) požádala, aby její podílný př́spěvek byl zvýšen na $20 \%$, čemuž bylo vyhověno. Tím došlo k úpravě výše př́ispěvkủ některých zemí, např. př́spěvek ČSR byl snížen z původních $7 \%$ na $5,75 \%$. SSSR si však výši svého podílného př́ispěvku podržel. V závěrečné dohodě a ve stanovách ústavu však bylo deklarováno, že bez ohledu na výši podílného členského prríspěvku, „všechny členské země ústavu mají stejná práva na účast v jeho vědecké činnosti a na jeho řízení." Účast pracovníků jiných než členských zemí na pracích ústavu (tj. kompenzace za využívání zařízení ústavu) byla řešena př́ípad od př́padu ředitelstvím ústavu. Archiv SÚJV, fond 3/1/1, dokument „MC/55/6“; Устав Объединенного института ядерных исследований, Глава 2, Сатья 6, [1956].

22 Archiv SÚJV, fond 3/1/1, dokument „MC/55/3“ (Pracovní program porady). 


\section{Vystoupení představitele československé delegace $\mathbf{v}$ diskusi na moskevské poradě}

Vedoucí československé delegace F. Vlasák se úvodního ani následujících pracovních zasedání porady neúčastnil a v tomto ohledu nebyl mezi vedoucími delegací výjimkou. Zúčastnil se až závěrečného zasedání 26 . března. Do té doby ho na zasedáních zastupoval J. Baier. ${ }^{23}$

V diskusi k úvodním referátům vystoupil za československou delegaci na zasedání 22. března $J$. Baier. $V$ poměrně dlouhém prríspěvku, který přednesl rusky, plně podpořil sovětské návrhy o ústavu. Zřízení ústavu označil za další krok sovětské pomoci zemím lidové demokracie při výzkumech a využití jaderné energie. Ocenil, že v ústavu bude možno pracovat nejen ve fyzice vysokých energií, ale také v aplikované jaderné fyzice, např. v oblasti výzkumu ,pokusných materiálů pro jaderné reaktory“. Jménem československé delegace podpořil názor, který zazněl v diskusi z více stran, že ústav by měl pracovat (a koordinovat spolupráci členských zemí) také v oblasti výzkumu kosmického záření. O možném přispění Československa $\mathrm{k}$ dobudování a počáteční činnosti ústavu uvedl stř́zlivě: „Př́spěvek Československa v oblasti jaderné fyziky a techniky nebude velký na počátku existence Východního ústavu. Co se týče kádrů, má Československo několik málo fyziků-teoretiků, kteř́ jsou na poměrně vysoké úrovni. Vedle toho by Východnímu ústavu mohli pomoci svými znalostmi českoslovenští inženýři, kteří prokázali své schopnosti v hraničních prríbuzných oborech a při stavbě urychlovačů některých typů. Výstavbě ústavu může napomoci také československý strojírenský průmysl, pro který je výroba jaderné techniky jedním ze základních perspektivních úkolů a který má dobré předpoklady pro výrobu elektrického zařízení a př́strojů pro jadernou fyziku a techniku“. 24

Československá delegace vypracovala také písemné připomínky k návrhu textu závěrečné Dohody. Podpořila např. zř́zení Finančního výboru jako orgánu ústavu, který by se zabýval hospodářko-finančními otázkami. ${ }^{25}$

\section{Závěrečná zasedání moskevské porady}

Na dopoledním zasedání 26. března 1956 byla vládními zmocněnci jedenácti zúčastněných zemí podepsána Dohoda o organizaci Východního ústavu jaderných výzkumů. Za Československou republiku Dohodu podepsal ministr F. Vlasák. Př́tomen byl také

23 Pro vybrané „VIP“ vládních delegací na moskevské poradě byl zřejmě zorganizován zvláštní program. Není vyloučeno, že souběžně probíhala další jednání o spolupráci v jaderných oborech; v čele delegací stáli totiž namnoze vedoucí představitelé národních autorit pro jadernou energii.

24 Archiv SÚJV, fond 3/1/1, dokument „MC/56/19“ (překlad z ruštiny E. T.).

25 Tamtéž, dokument „MC/56/27“. Zřízení Finančního výboru bylo přijato a do návrhu Dohody doplněno. Bylo zakotveno v článku VII, v němž se pravilo, že pro schvalování rozpočtu a kontrolu finanční činnosti Ústavu se zřizuje Finanční výbor z představitelů všech členských států. Každý členský stát má ve Finančním výboru jednoho představitele. Členy Finančního výboru jmenují vlády členských zemí ústavu. Finanční výbor se měl scházet alespoň jednou ročně. Na základě návrhu předloženého na zasedání vládních zmocněnců v září 1956 byl však Finanční výbor z důvodů efektivity práce zrušen a jeho kompetence přeneseny na Sbor vládních zmocněnců (přejmenovaný na Výbor vládních zmocněnců), který se měl původně scházet jen za účelem volby ředitele a jeho náměstků (nově alespoň jednou ročně). V 60. letech, kdy vyvstaly potíže s financováním SÚJV (v souvislosti s postoji Č́ny a Rumunska), byl Finanční výbor SÚJV znovu ustanoven. 
československý velvyslanec v SSSR Jaromír Vošahlík. Po podpisu Dohody bylo vládními zmocněnci signatářských zemí zvoleno první ředitelství ústavu: ředitel D. I. Blochincev (Sovětský svaz) a jeho dva náměstci (zástupci ředitele) pro vědeckou činnost Marian Danysz (Polsko) a Václav Votruba (Československo). Tomuto ředitelství bylo uloženo, aby do tří měsíců vypracovali a předložili návrh stanov ústavu. Schváleno bylo dále prohlášení o zřízení ústavu pro tisk a přizvání k členství v ústavu vlády Vietnamské demokratické republiky (která na odeslaný telegram obratem kladně odpověděla a v záŕí 1956 byla vládními zmocněnci přijata za dvanáctou členskou zemi ústavu).

Dodatečně, na večerním zasedání 26. března, byl vládními zmocněnci schválen návrh změny názvu Východního ústavu jaderných výzkumů na Spojený ústav jaderných výzkumů (rusky Объединенный институт ядерныхх исследований, anglicky Joint Institute of Nuclear Research). Návrh, který vzešel z diskuse, cílil na odstranění čehokoli z názvu ústavu, který měl být mezinárodním ústavem, co by naznačovalo politickou opozici mezi Východem a Západem. Změna názvu, po odsouhlasení sovětskými orgány, byla zanesena do již podepsané Dohody. ${ }^{26}$

\section{Reflexe zř́zení Spojeného ústavu jaderných výzkumů v československém tisku}

Zprávu o podepsání Dohody o zř́zení Spojeného ústavu jaderných výzkumů se sídlem v Moskvě, převzatou z Tiskové agentury Sovětského svazu (TASS), přineslo Rudé právo 27. března 1956. ${ }^{27}$ Následujícího dne, 28. března byl v Rudém právu uveřejněn další článek s titulkem Významný př́spěvek k rozvoji mezinárodní vědecké spolupráce. ${ }^{28}$ Dne 29. března, den po návratu československé delegace z moskevské porady, přinesl týž deník rozhovor se zástupcem vedoucího delegace ing. J. Baierem. Na otázku o mezinárodním významu zřízení SÚJV Baier poukázal na finanční nákladnost zařízení potřebných pro úspěšný výzkum ve fyzice elementárních částic a atomového jádra. Uvedl, že SÚJV umožní československým pracovníkủm ,stát v prední linii, studovat základni teoretické problémy, které dnes řeši jaderná fyzika“. Dodal, že zřízením SÚJV „se nikterak nesnižuje význam našeho Ústavu jaderné fysiky, který je zaměren předevšim na využití jaderné fysiky v energetice a použivání radioaktivnich isotopü“. Zopakoval, že Československo může SÚJV bezprostředně nabídnout pomoc svého vyspělého strojírenství, ,pro něž je výroba zařizení jaderné techniky jedním z hlavních výhledových úkoli̛ “. Dále uvedl, že práce v SÚJV se může zúčastnit kterákoli země, která bude souhlasit se zněním Dohody, požádá o přijetí a bude přijata prostou většinou. K článku byla připojena fotografie skupiny účastníků

26 Archiv SÚJV, fond 3/1/1, dokument „MC/56/45“. Změnu názvu ústavu konzultovali A. V. Topčijev a S. K. Carapkin s ministrem zahraničních věcí SSSR V. M. Molotovem přípisem z 24. března 1956; schválena byla usnesením prezídia ÚV KSSS z 26. března. Srov. Б. М. СтАРченко - Ю. Г. ШИМАНСКАЯ - И. Ю. ЩЕРБАКОВА (eds.), История создания ОИЯИ, s. 28.

27 Závěrečná zpráva mezinárodni konference 11 států v Moskvě. Dohoda o zrrizeni , Spojeného ústavu jaderných výzkumů “ se sídlem v SSSR, Rudé právo (dále RP) 36/87, 27. 3. 1956, s. 3. V této zprávě však nebyla uvedena jména osob, které jako zmocněnci svých vlád Dohodu podepsali. Plný text Dohody, již s opraveným názvem ústavu a jmény všech podepsaných vládních zmocněnců, byl publikován v moskevské Pravdě až 12 . července 1956.

28 Významný př́spěvek k rozvoji mezinárodni vědecké spolupráce, RP 36/88, 28. 3. 1956, s. 3. 
moskevské porady při prohlídce synchrofázotronu $10 \mathrm{GeV}$ v Elektrofyzikální laboratoři AV SSSR. ${ }^{29}$ Dodatečně, dne 1. dubna 1956 byla v Rudém právu otištěna panoramatická fotografie tohoto urychlovače s popiskou uvádějící jeho ohromující parametry: prstencový elektromagnet váží 36 tisíc tun a má průměr 60 metrů..$^{30}$ Ve vazbě na zř́zzení SÚJV a československou účast $\mathrm{v}$ tomto ústavu byl pak $\mathrm{v}$ Rudém právu 8. dubna 1956 uveřejněn také článek M. Seidla o urychlovačích částic, zahrnující informace o vývoji československého betatronu (a fotografie prvých dvou modelů tohoto urychlovače elektronů). ${ }^{31}$

\section{Okolnosti návrhu a volby Václava Votruby náměstkem ředitele SÚJV}

V. Votruba ani M. Danysz se moskevské porady nezúčastnili, náměstky ředitele ústavu byli zvoleni v nepř́tomnosti. Ve zprávě československé delegace o účasti na poradě se uvádí, že návrh, aby na post jednoho náměstka ředitele Východního ústavu jaderných výzkumů byl navržen někdo z československých vědců, předložil akademik Topčijev. Československá delegace se $\mathrm{k}$ návrhu ,postavila kladně, $i$ když si byla vědoma velkého nedostatku čs. fysikủ takového formátu. Byla si vědoma velkého významu pro dalši rozvoj československé vědy, bude-li čs. vědec pracovat na tak významném misté Ústavu, i toho, že je to pro československou vědu velké vyznamenání. Delegace došla k názoru, že může navrhnout prof. Votrubu a s. Šimáně. Kandidatura prof. Votruby byla schválena náměstkem předsedy vlády V. Kopeckým telefonicky dne 24. 3. 1956 s. Vlasákovi. Se s. Votrubou, který byl právě v Sofii, se delegace domluvila telefonicky a s. Votruba kandidaturu prijjal.“32

Kandidatura V. Votruby na nabídnuté místo náměstka ředitele byla z československé strany optimálním řešením. Václav Votruba, tehdy 47letý člen korespondent ČSAV, profesor teoretické fyziky na Fakultě technické a jaderné fyziky UK a doktor fyzikálně-matematických věd, byl v zahraničí známým a respektovaným teoretickým fyzikem. Publikoval (zpravidla souběžně česky a cizojazyčně) práce $\mathrm{z}$ teorie relativity, kvantové elektrodynamiky a teorie elementárních částic, $v$ nichž se zabýval aktuálními problémy, jakými byly např. „problém elektronových trojčat“", zobecněná teorie nukleonů a mezonů, rozpad mezonů $\mu$ (společně se svým aspirantem Č. Muzikářem), klasifikace elementárních částic na základě izotopického spinu (společně se svým aspirantem M. Lokajíčkem a s bulharským fyzikem

29 Př́klad mezinárodní spolupráce ve védě. Rozhovor s účastníkem konference o zř́zení Spojeného ústavu jaderných výzkumů, RP 36/89, 29. 3. 1956, s. 1.

30 RP 36/92, 1. 4. 1956, s. 5.

31 Miloš SeIDL, Urychlovače atomových částic, RP 36/98, 8. 4. 1956, s. 3. V závěru článku autor uvedl: „Snad bude čtenáře zajímat, že i u nás se začnou vyrábět betatrony. Koncem roku 1953 byli pracovníci Výzkumného ústavu pro vakuovou elektrotechniku v Praze postaveni před úkol zhotovit pro vlastní výzkumné účely zdroj rychlých elektronů. Rozhodli se, že budou úkol řešit tak, aby získaných zkušeností mohli později využít pro vývoj silného zdroje gamma záření pro průmysl a lékařství. $Z$ toho důvodu padla volba na betatron. Již v polovině roku 1954 byl v ústavě uveden do chodu první československý betatron, který urychluje elektrony na energii 2 miliony elektronvoltů. Začátkem minulého roku byl zahájen vývoj komerčního betatronu, který bude urychlovat elektrony na energii 15 milionů elektronvoltů. Aby se co nejvíce zkrátila cesta od vývoje až po zavedení výroby, podílí se na vývoji betatronu Výzkumný ústav pro vakuovou elektrotechniku, který jej řeší po stránce funkční, a ČKD Stalingrad, který jej řeší po stránce konstrukční a připravuje jeho výrobu. Již v př́ištím roce budou v provozu první zkušební betatrony a v roce 1958 bude zahájena jejich výroba.“

32 NA, fond ÚPV, doklady k usnesení vlády RČS č. 2038 ze dne 9. 8. 1956. František Vlasák, Zpráva čs. delegace o průběhu a výsledcích Mezinárodní konference o organizaci Spojeného ústavu pro jaderný výzkum, 20.-26. 3. 1956 v Moskvě (dat. 24. 7. 1956). 
Ch. J. Christovem). ${ }^{33}$ Votruba také jako jeden z prvních československých fyziků navázal vědecké kontakty se sovětskými teoretickými fyziky. ${ }^{34}$ Členem KSČ nebyl, kádrový profil mu mírně vylepšoval tzv. dělnický původ, protože jeho otec i matka pracovali v dělnických profesích. Kandidaturu na post náměstka přijal, jinou možnost nejspíš neměl.

Elektroinženýr Č. Šimáně (1919-2012), byt’ o deset let mladší než V. Votruba, byl již také respektovanou a mezi sovětskými odborníky v jaderné fyzice a technice známou osobou. Po kádrové stránce byl dobře prověřený. Jeho uvolnění pro post náměstka ředitele SÚJV by však jistě zkomplikovalo dobudování československého Ústavu jaderné fyziky a jednání o dalších smělých plánech ve výzkumu a využití jaderné energie v Československu. A také mu chyběly vyšší akademické hodnosti, které byly u kandidátů na post náměstka ředitele SÚJV bezesporu žádoucí.

\section{Nástin profesní kariéry a kádrového profilu V. Votruby do zvolení náměstkem ředitele SúJV}

Václav Votruba (1909-1990) absolvoval studium matematiky a fyziky na Př́rodovědecké fakultě UK, které zakončil v roce 1933 státní zkouškou opravňující k výuce matematiky a fyziky na středních školách. $K$ jeho vysokoškolským učitelům patřili profesoři teoretické fyziky František Záviška a Viktor Trkal.

Od 1. října 1934, po absolvování roční prezenční vojenské služby, V. Votruba nastoupil na Přírodovědecké fakultě UK na místo pomocné vědecké síly v Ústavu pro teoretickou fyziku vedeném profesorem Záviškou; jediné místo asistenta v ústavu bylo obsazené, zastával je Karel Teige, který byl $\mathrm{v}$ té době již habilitovaný a měl titul mimořádného profesora. V. Votruba vypomáhal v ústavu jako pomocná vědecká síla již za studií (kdy zastupoval Ladislava Zachovala po dobu jeho prezenční vojenské služby). Po studiích místo zastával prakticky až do zář́ 1937, kdy nastoupil jako středoškolský profesor na Masarykovo reálné gymnázium v Praze na Vinohradech. ${ }^{35}$ Mezi tím, v červnu 1936 se oženil. Na střední škole

33 Bibliografie vědeckých prací V. Votruby zahrnuje 21 položek publikovaných do roku 1956 (včetně samostatně vykazovaných paralelních publikací téže práce v češtině a cizojazyčně).

34 Konkrétně v roce 1955, ve dnech 31. března - 7. dubna, se V. Votruba zúčastnil Všesvazové konference (porady) o kvantové elektrodynamice a teorii elementárních částic v Moskvě, která byla organizována AV SSSR. Vedle řady sovětských teoretických fyziků se konference zúčastnili jako pozvaní zahraniční hosté fyzici z Bulharska, Československa (V. Votruba), ČLR, Mad’arska, NDR, Polska, Rumunska a Švédska. V. Votruba zde přednesl př́spěvek o symetrickém popisu částic a antičástic na základě izotopického spinu (,Symmetrical treatment of baryons and antibaryons"). V cestovní zprávě uvedl, že na konferenci bylo předneseno přes 50 referátů a množství dotazů a diskusních příspěvků týkajících se nejaktuálnějších otázek kvantové teorie pole a elementárních částic. „Ukázalo se, že Sovětský svaz má velký počet pracovníků, kteří mistrně ovládají tento základní obor dnešní theoretické fysiky a z nichž mnozí originálním způsobem a s vynikajícím úspěchem přispívají k řešení jeho hlavních problémů." Votruba spolu s několika dalšími hosty konference přednášel také v semináŕi profesora D. D. Ivaněnka ve Fyzikálním ústavu na Moskevské státní univerzitě. V závěru cestovní zprávy konstatoval: „Konference byla velmi užitečná a úspěšná. Umožnila širokou a bezprostřední výměnu názorů, výsledků a zkušeností nejen sovětským fysikům mezi sebou, ale i mezi sovětskými a zahraničními fysiky, jimž dala nahlédnouti též do stylu práce sovětských fysikủ a umožnila navázat s nimi osobní známosti a přátelské styky. Jest doufati, že tyto styky bude možno nejen udržovati, ale i dále rozvíjeti ve skutečnou spolupráci.“ MÚA, fond Sbírka cestovních zpráv, SSSR, 1954-1955. Václav Votruba, Všesvazová konference o kvantové elektrodynamice a teorii elementárních částic v Moskvě (s. d.).

35 V životopise z ledna 1950 V. Votruba k počátku své profesní kariéry uvedl: „Po složení státních zkoušek z matematiky a fysiky na jaře r. 1933 jsem po prázdninách téhož roku nastoupil čtrnáctiměsiční presenční 
působil i za války, s přerušením v letech 1941-1944, kdy byl přikázán službou k Ústřednímu ústavu meteorologickému v Praze, a od listopadu 1944 prakticky až do konce války, kdy byl pracovně nasazen jako pomocný dělník na stavbě Vinohradského železničního tunelu v Praze. ${ }^{36}$

V květnu 1945, po osvobození a v souvislosti s obnovou činnosti českých vysokých škol, vyzval profesor Trkal (zvolený v květnu 1945 děkanem Př́rodovědecké fakulty UK) $\mathrm{V}$. Votrubu, aby nastoupil na fakultu jako asistent a pomohl zajistit výuku teoretické fyziky v poválečném zkráceném semestru; V. Trkal byl zavalen vědecko-organizační prací na fakultě a v České akademii věd a umění (kde zastával funkci generálního tajemníka) a F. Záviška, za války zatčený a deportovaný do koncentračního tábora, byl zatím nezvěstný. K působení na vysoké škole byla Votrubovi na střední škole udělena dovolená, která mu pak byla opakovaně prodlužována, protože F. Záviška při návratu z koncentračního tábora v Německu dne 17. dubna 1945 následkem vysílení zemřel; až do roku 1950 byl však Votruba nadále veden ve stavu profesorů středních škol. Na Přírodovědecké fakultě UK převzal po profesoru Záviškovi přednášku Přehled teoretické fyziky, která byla součástí čtyřsemestrálního cyklu, a Seminář z klasické teoretické fyziky. ${ }^{37}$ Hned v roce 1945 také dokončil svou doktorskou disertaci „O Lorentzově kovarianci polních rovnic“ a byl promován doktorem př́rodních věd. ${ }^{38}$

V srpnu 1947, na základě stipendia ministerstva školství a osvěty, V. Votruba odjel na roční studijní pobyt do Švýcarska, do Curychu, kde v té době působili dva vynikající odborníci v kvantové teorii - na univerzitě G. Wentzel a na technice W. Pauli. Pobyt dojednal profesor Trkal osobně s profesorem Wentzelem, vedoucím Fyzikálního ústavu curyšské univerzity. Votruba během pobytu navštěvoval vybrané přednášky a semináře na curyšské

službu vojenskou. V říjnu r. 1934 jsem se vrátil na místo věd. pomocníka do ústavu pro theoretickou fysiku, nebot' aprobovaných kandidátů profesury bylo tenkrát tolik, že na místo profesora na střední škole bylo nutno několik let čekat. Po dva roky mohl jsem se pak v poměrném klidu věnovat studiu moderní odborné literatury a pokusům o vlastní vědeckou práci. Škoda, že jsem tehdy postrádal zkušeného a zasvěceného vedení; prof. Záviška se tehdy zabýval zcela jinými problémy, než byly ty, o něž jsem se zajímal sám. To byla jistě jedna z příčin, proč mé pokusy o vlastní věd. práci neskončily tehdy zdarem.“" Archiv Univerzity Karlovy, Praha (dále AUK), fond Matematicko-fyzikální fakulta UK (dále MFF UK), Osobní spis (dále OS) Votruba Václav. Životopis dr. Václava Votruby. Př́loha k „Dotazníku č. 1“ MŠVU (dat. 9. 1. 1950).

36 Od 1. záŕí 1940 do 31. srpna 1943 V. Votruba učil na reálném gymnáziu v Praze v Křemencově ulici, po válce byl veden ve stavu profesorů gymnázia v Praze, Truhlářské ulici.

37 V tištěných seznamech přednášek ohlašovaných fakultami Univerzity Karlovy bylo jméno V. Votruby ve stavu přednášejících na Přírodovědecké fakultě UK poprvé uvedeno ve studijním roce 1949/50, a to mezi suplujíími učiteli pověřenými přednáškami. Jako přednášející byl jmenovitě uveden až ve školním roce 1950/51, a to u přednášek Teorie elementárních částic (zimní semestr), Teorie elementárních kvantových procesů (zimní semestr), Teorie elektromagnetického pole (letní semestr) a u Semináře II: Cvičení z teorie elektromagnetického pole (letní semestr). AUK, Seznamy přednášek, Př́rodovědecká fakulta UK (dále PřF UK), školní roky 1945/46 až 1950/51. Část přednášek z teoretické fyziky suploval na PřF UK po válce také RNDr. Miroslav Brdička, např Úvod do teoretické fysiky I, II a Proseminář z teoretické fyziky. I jemu byla za tím účelem tehdy udělena dovolená na střední škole; do stavu zaměstnanců fakulty byl převeden až k 1. červenci 1949. Srov. E. TĚŠínSKÁ, Miroslav Brdička, několik biografických dat, Československý časopis pro fyziku (dále Čs. čas. fyz.) 60,2010 , s. $158-164$.

38 Práce byla publikována česky a francouzsky matematicko-př́rodovědnou tř́ídou České akademie věd a umění (ČAVU). V. VotruBA, O Lorentzově kovarianci polnich rovnic, Rozpravy II. třídy České akademie věd a umění 56/11, 1946, 23 s. (datováno: Ústav pro teoretickou fyziku univerzity Karlovy v Praze v ř́innu 1946, k publikaci předloženo 15. 11. 1946); TÝž, A propos de la covariance d'équations de champs physiques par rapport au groupe de Lorentz, Bulletin international de l'Académie tchèque des sciences 47, 1946, Prague 1950, s. 79-90 (předloženo k publikaci 15. 11. 1946, v závěru autor děkuje profesoru V. Trkalovi za inspiraci k tématu a profesoru V. Hlavatému za kritické názory). 
univerzitě i technice. Ve Fyzikálním ústavu univerzity se z podnětu profesora Wentzela začal zabývat problémem tzv. materializace paprsků gama v poli elektronu, tj. interakcí elementárních částic $\gamma+\mathrm{e}^{-} \rightarrow \mathrm{e}^{-}+\mathrm{e}^{+}+\mathrm{e}^{-}$(dnes označováno jako ,problém elektronových trojčat"“). Na základě kvantové elektrodynamiky (Diracovy teorie pozitronu ve formulaci kvantové teorie polí) spočetl účinný prưřez tohoto procesu pro určitý obor energií fotonu. Práci, která představovala do té doby nejúplnější řešení problému, dokončil po návratu ze stáže a publikoval v roce 1948 v krátkém anglickém souhrnu v časopise Physical Review a poté v plném znění česky a anglicky v České akademii věd a umění. ${ }^{39} \mathrm{Na}$ základě této práce se v roce 1949 na Přírodovědecké fakultě UK habilitoval. Od 1. dubna 1950 byl pak převeden ze střední školy do stavu zaměstnanců fakulty, jmenován odborným asistentem a od 1. května 1951 ministerstvem (konečně) potvrzen jako docent pro obor fyziky. ${ }^{40}$ Poté se stal také školitelem aspirantů v oboru teoretické fyziky; jeho prvními aspiranty (které školil neoficiálně již od roku 1950) byli Čestmír Muzikář a Miloš Lokajíček. Pod vedením V. Votruby začal v oboru fyziky elementárních částic pracovat také slovenský fyzik Immrich Staríček. ${ }^{41}$

Proti návrhu na jmenování V. Votruby profesorem teoretické fyziky, který byl předložen v rámci tehdejšího Vědeckého odboru fyziky a příbuzných oborů na Přírodovědecké fakultě UK v polovině roku 1951, byla uplatněna skutečně absurdní námitka, že Votruba publikoval své práce ,i na západě“، V. Votrubovi byla poté Př́rodovědeckou fakultou Masarykovy univerzity v Brně nabídnuta profesura teoretické fyziky uvolněná úmrtím (12. dubna 1951) Bohuslav Hostinského. K uvolnění Votruby Přírodovědeckou fakultou UK však nedošlo (a Votruba sám neměl o místo zájem).

39 V. Votruba, Pair Production by Gamma-Rays in the Field of an Electron, Physical Review 73, 1948, s. 1468 (vyšlo 15. června 1948); TÝž, Theorie materialisace paprsků gamma v poli elektronu, Rozpravy II. tř́idy ČAVU 58/4, 1948, 43 s. (předloženo k publikaci 14. 5. 1948); Tŕž, Pair Production by Gamma-Rays in the Field of an Electron, Bulletin international de l'Académie tchèque des sciences 49, 1948, Prague 1950, s. 19-49 (datováno v Ústavu pro teoretickou fyziku UK, březen 1948; předloženo k publikaci 14. 5. 1948). Proces možného vzniku elektron-pozitronového páru anihilací kvanta gama v poli elektronu předpověděl v r. 1934 francouzský fyzik F. Perrin, částečnou teorii procesu podali ještě před druhou světovou válkou J. Wheeler a W. E. Lamb, experimentálně proces zaregistrovali v r. 1945 W. E. Ogle a P. G. Krüger v USA na fotografiích z mlžné komory ozářených $\gamma$-zářením ThC'. Současně s V. Votrubou se problémem nezávisle zabývali A. Borallino v Itálii (Miláně) a K. M. Watson v USA, kteří své výsledky publikovali koncem r. 1947 a počátkem r. 1948. V r. 1948 publikoval práci o tomto problému také ruský fyzik P. E. Němirovskij z Fyzikálního ústavu P. N. Lebeděva AV SSSR v Moskvě. AUK, fond MFF UK, OS Votruba Václav. Posudek habilitační komise z 28. února 1949 (referent V. Trkal). O vědeckých pracích V. Votruby viz též Jiří FormÁnek, Život a dílo profesora Václava Votruby, Čs. čas. fyz. 50, 2000, s. 233-245.

40 Všechny kroky habilitačního řízení V. Votruby na PřF UK proběhly zdárně v první polovině roku 1949. V souvislosti s přípravou nového vysokoškolského zákona však ministerstvo školství věd a umění habilitaci potvrdilo až př́ípisem z 11. záríi 1951, a to s účinností od 1. května 1951. AUK, fond MFF UK, OS Votruba Václav. Přípis Ministerstva školství, věd a umění z 11. 9. 1951, adresovaný V. Votrubovi, odbornému asistentu PřF UK. Podobně tomu bylo v př́padě habilitace pro teoretickou fyziku Zdeňka Matyáše (1914-1957). I jeho habilitační řízení na PřF UK proběhlo zdárně již v roce 1949, docentem (pro obor fyzika) byl však jmenován rovněž až S účinností od 1. ř́ína 1951. V r. 1955 byl jmenován profesorem teoretické fyziky (pevných látek) a od 1. 2. 1957 vedoucím katedry teoretické fyziky na MFF UK. AUK, fond MFF UK, OS Matyáš Zdeněk.

41 Během krátkého studijního pobytu u V. Votruby v únoru 1951 se I. Staríček začal zabývat teorií dvoufotonové anihilace pozitronu a elektronu. AUK, fond MFF UK, OS Votruba Václav. Návrh na jmenování V. Votruby profesorem teoretické fyziky na PřF UK z roku 1951 (s. d.). Podobně jako M. Lokajíček (viz dále v textu), byl I. Staríček (1919-2002) v r. 1954 odsouzen za vlastizradu pro aktivní účast v katolickém společenství „Rodina“. Z vězení byl propuštěn na amnestii v r. 1962. Zlatica PlašıenkovÁ, Za Imrichom Staríckom, Filozofia 57, 2002, s. 377-379. 
Ve školním roce 1952/53 byl V. Votruba jako docent převeden na nově zřízenou Matematicko-fyzikální fakultu UK, kde byl v květnu 1953 pověřen vedením oddělení atomistiky a fyziky pevných látek při katedře fyziky. ${ }^{42}$ Návrh na jeho jmenování profesorem byl fakultou v březnu 1953 urgován; ve zdůvodnění bylo mj. uvedeno, že „Votruba získal v důsledku svých vysoce oceněných prací slib z leningradské university, že jeho publikace boudou v Leningradě vždy bezodkladně publikovány“،.43 Téhož roku, dne 23. listopadu 1953, byl V. Votruba zvolen členem korespondentem nové Československé akademie věd. V polovině roku 1954, dopisem z 24. června, se hlavní sekretář ČSAV akademik F. Šorm obrátil na rektora Univerzity Karlovy profesora M. Katětova se žádostí o uvolnění profesora Votruby z Matematicko-fyzikální fakulty UK do Fyzikálního ústavu ČSAV, aby tam vedl oddělení fyziky atomového jádra a elementárních částic. K uvolnění Votruby fakultou (opět) nedošlo, s odůvodněním potřeby zajistit výuku. Na základě rozhodnutí prezidenta A. Zápotockého z 12. listopadu 1954 byl však Votruba konečně jmenován vysokoškolským profesorem. ${ }^{44}$

Ve školním roce 1955/56 byl profesor Votruba převeden z Matematicko-fyzikální fakulty UK na nově zřizenou Fakultu technické a jaderné fyziky UK, společně s profesorem V. Petržílkou, který se stal prvním děkanem této fakulty. Počátkem roku 1956, na zasedání Státní komise pro vědecké hodnosti 29. února, byla V. Votrubovi udělena vědecká hodnost doktora fyzikálně-matematických věd (DrSc.) a v březnu 1956 následovalo jeho zvolení náměstkem ředitele Spojeného ústavu jaderných výzkumů.

Ke kádrovému profilu V. Votruby připojuji citaci z důvěrného posudku, který byl vypracován vedoucím katedry fyziky na Přírodovědecké fakultě UK profesorem L. Zachovalem v roce 1951. V posudku se uvádělo: „Dr. Václav Votruba působí jako asistent v ústavu pro teoretickou fyziku univerzity Karlovy. Vypracoval se obtižně, a vétšinou bez náležitého odborného vedení, na dobrého pracovníka v oboru kvantové teorie. Obirá se prevážně teorii elementárních částic. Jeho práce se vyznačují dokonalým provedením a jsou založeny na solidních a širokých vědomostech.

Jako pedagog se osvědčuje dobře pro posluchače vyššich semestrů, práci se věnuje svědomitě a piše také skripta. Velmi mnoho práce věnoval reformě vysokoškolského studia jako člen reformni komise na přrrodovědecké fakultě i na katedře fysiky.

Propracuje-li se v noetických otázkách k dialektickému materialismu, bude moci vykonat velmi mnoho práce pro ozdravění fysiky u nás. Už nyní je jeho působení - preses noetickou rozkolísanost a neujasněnost - kladné, což se opírá o jeho vysokou odbornou úroveň.“45

42 Koncem roku 1954 V. Votruba požádal o uvolnění z funkce vedoucího katedry (dříve oddělení) atomistiky a fyziky pevných látek s odůvodněním, že je zaneprázdněn úkoly, kterými byl pověren v I. matematicko-fyzikální sekci ČSAV. Jeho žádosti bylo vyhověno přípisem ministra školství z 16. června 1955. Novým vedoucím katedry se stal M. A. Valouch. AUK, fond MFF UK, OS Votruba Václav.

43 AUK, fond MFF UK, OS Votruba Václav. Př́loha dopisu děkana MFF UK k Rektorátu UK ze dne 5. 3. 1953.

44 AUK, fond MFF UK, OS Votruba Václav. Jmenování doc. dr. Václava Votruby profesorem (kopie připojená k přípisu děkanátu MFF UK z 5. 3. 1953).

45 AUK, fond MFF UK, OS Votruba Václav. Vedoucí katedry fyziky L. Zachoval děkanátu PřF UK, 22. 10. 1951, opis, označeno jako „Důvěrné“. 


\section{Všesvazová konference o fyzice částic vysokých energií v Moskvě}

Krátce po moskevské poradě o Východním (Spojeném) ústavu jaderných výzkumů se V. Votruba spolu s V. Petržílkou a M. Seidlem zúčastnili Všesvazové konference o fyzice částic vysokých energií, která se konala ve Fyzikálním ústavu P. N. Lebeděva v Moskvě ve dnech 14.-22. května 1956. Na konferenci byla př́tomna řada zahraničních fyziků, včetně západních. Několik zasedání bylo věnováno urychlovačům částic. V. I. Veksler zde referoval o synchrofázotronu budovaném v Elektrofyzikální laboratoři AV SSSR (zaslíbené již SÚJV) a E. Regenstreif zase O synchrotronu $25 \mathrm{GeV}$ budovaném v CERN. M. Seidl přednesl v sekci elektronových urychlovačů př́spěvek k problematice záchytu elektronů v betatronu. Historickou zajímavostí je, že V. Petržílka byl z této konference telegraficky odvolán československým VVAE, aby 22. května odjel s delegací československých pracovníků v jaderné a technické fyzice do Jugoslávie; není vyloučeno, že předmětem jednání československé delegace $\mathrm{v}$ Jugoslávii tehdy byla i otázka účasti Jugoslávie v SÚJV.46

\section{Usnesení vlády ke zprávě československé delegace o účasti na moskevské poradě o SúJV}

Po návratu z moskevské porady o SÚJV podal vedoucí československé delegace F. Vlasák Vládnímu výboru pro výzkum a mírové využití atomové energie zprávu o průběhu a výsledcích porady. Nařízením vlády č. 19 ze dne 16. června 1956, jak již bylo zmíněno, byl však VVAE zrušen. ${ }^{47}$ Jako orgán př́slušný pro styk s SÚJV byla poté, vládním usnesením č. 2038 z 9. srpna 1956, ustanovena Československá akademie věd. V rámci ČSAV byla agenda SÚJV „,o se týče rozhodování o zásadních i administrativních otázkách“ podř́zena Výboru prezídia. ${ }^{48}$ Zprávy o československé účasti na zasedání orgánů SÚJV

46 MÚA, fond Sbírka cestovních zpráv, SSSR, 1956. Cestovní zpráva podaná společně V. Petržílkou a V. Votrubou (s. d.). Srov. též publikovanou zprávu o konferenci: В. А. БиРюков - Б. М. Головин - Л. И. ЛАПидус, Всесоюзная конференция по физике частиц высоких энергий, Атомная энергия 1, 1956, s. 158-166.

47 Vláda tímto nařízením ,zabezpečila“ usnesení II. celostátní konference KSČ, která se konala ve dnech 11.-15. června 1956. V usnesení konference bylo v rámci decentralizačních opatření navrženo zrušení celkem devíti ministerstev, ústředních úřadů a institucí. Ve zdůvodnění se mj. uvádělo:,Všechna navrhovaná opatření ve svém celku zpružní řízení našeho hospodářství a vytvoří předpoklady k odstranění přebujelosti administrativního aparátu, který vedle celého centralistického systému rrízení i sám je zdrojem a semeništěm byrokratických metod práce. V souvislosti se zjednodušováním řízení, plánování, zásobování a financování národního hospodářství je proto třeba na všech úsecích přistoupit k odstranění všeho zbytečného a často duplicitního administrování a na tom základě dosáhnout jak zkvalitnění aparátu, tak i snížení stavů pracovníků. “ NA, fond ÚV KSČ, 1956-1962, i. č. 51, sv. 5. II. celostátní konference KSČ, 11.-15. 6. 1956.

48 Vyřizování agendy československé spolupráce s SƯJV probíhalo nicméně, a to nejen v prvních letech této spolupráce, po více kolejích, např. přes československé velvyslanectví v Moskvě, kde nadále působil jako styčná osoba pro otázky atomové energie ing. F. Kovár. Dokládá to např. záznam z jednání J. Kožešníka s V. Votrubou v Praze před zasedáním Výboru vládních zmocněnců v listopadu 1957. V záznamu se uvádí: „Pokud jde o pravomoc a povinnosti s. Ing. Kováře ve vztahu k SÚJV a ÚJF a ČSAV, věc není jasná ani prof. Kožešníkovi ani prof. Votrubovi. Některé zprávy dostává Ing. Kovář výhradně sám, některé naším prostřednictvím, některé ČSAV prostřednictvím Ing. Kováře a pod.“ MÚA, fond Zahraniční odbor prezídia ČSAV, k. 77, Jaderný výzkum. Stručný záznam o jednání s. prof. Kožešníkem a prof. Votrubou ohledně problémů SÚJV, bod 3 (s. d.). Kompetenční otázky bylo nutno řešit také v souvislosti s již zmíněným zrušením Finančního výboru SÚJV (přenesením jeho pravomocí na Výbor vládních zmocněnců), kdy bylo nutno rozhodnout, zda 
a všechna zásadnější rozhodnutí (o financování, vysílání československých pracovníků a podobně) byly předkládány ke schválení vládě a stranickým orgánům.

\section{Nástup V. Votruby do funkce náměstka ředitele SÚJV}

Funkční období prvního ředitelství SÚJV se formálně počítalo od podepsání dohody o zřízení ústavu v březnu 1956, reálně však toto ředitelství začalo pracovat až v létě t. r., poté co byly SÚJV administrativně předány oba přislíbené ústavy AV SSSR.

První korespondence SÚJV s členskými zeměmi byla vedena jménem ředitele Blochinceva. Dopisem z 25. července 1956 se ředitel Blochincev obrátil na československého velvyslance J. Vošahlíka a požádal ho, aby tlumočil československé vládě žádost o vyslání „Václava Josifoviče“ Votruby do Sovětského svazu za účelem výkonu funkce náměstka SÚJV, a to nejpozději k 1. záŕí $1956 .{ }^{49}$ Poté, pokynem ministra školství a kultury Františka Kahudy z 20. srpna 1956, byl Votruba uvolněn z pedagogické činnosti na Fakultě technické a jaderné fyziky UK na dobu od 1. záŕí 1956 do dalšího rozhodnutí, ,aby mohl vykonávat funkci náměstka ředitele SÚJV v SSSR“. Dnem 31. srpna 1956 mu bylo také zastaveno vyplácení dosavadních pracovních př́ijmů s tím, že bude dostávat plat od „druhé strany“. ${ }^{50}$ Vyřízení formalit spojených s jeho odjezdem do Dubny zajistil Zahraniční odbor prezídia ČSAV (na základě usnesení Výboru prezídia ČSAV z 15. srpna 1956). Jak dokládá telegram odeslaný řediteli Blochincevovi, V. Votruba odjel z Prahy do Dubny dne 1. záríi $1956 .{ }^{51}$

K prvním dopisům, podepsaným ředitelem Blochincevem a oběma jeho náměstky (byt' v té době ještě zjevně na své posty v Dubně nenastoupili), patřilo oslovení vlád členských zemí ve věci vyslání prvních pracovníků do SÚJV. Československá vláda byla v této věci oslovena prostřednictvím dopisu z 26. července 1956 adresovaného československému velvyslanci J. Vošahlíkovi. V dopise bylo uvedeno, že ředitelství SÚJV považuje za možné již v roce 1956 přijmout do ústavu 50-60 pracovníků členských zemí (míněno mimo SSSR), a byla vyslovena žádost o předložení návrhů konkrétních osob (formou vyplněných dotazníků) do 1. září t. r. Žádáni byli jak kvalifikovaní specialisté schopní vést jednotlivé vědecké směry a metodické práce, tak vědečtí pracovníci, kteří by si v ústavu zvýšili kvalifikaci v oboru jaderné fyziky, jaderné techniky a využití urychlovačů. Bylo uvedeno, že ústav potřebuje zejména vědeckého vedoucího nově projektované Laboratoře neutronové fyziky a vysoce kvalifikovaného radiochemika pro vedení všech radiochemických prací v ústavu (zejména v souvislosti s budováním Laboratoře neutronové fyziky a urychlovače vícenásobných iontů). Výčet dalších volných pozic byl připojen v př́loze. Zároveň bylo

československým zmocněncem - členem Výboru vládních zmocněnců pro SÚJV bude nadále J. Kožešník, nebo F. Kovář ze zrušeného Finančního výboru. Zmocněncem zůstal J. Kožešník, strojní inženýr a profesor ČVUT, člen korespondent a činovník (v té době zástupce hlavního vědeckého sekretáře) ČSAV.

49 Archiv SÚJV, fond 3/1/21, zn. „OI-164“.

50 AUK, fond MFF UK, OS Votruba Václav. Opis dopisu ministra školství a kultury, čj. 47 194/56-B/1 (na hlavičkovém papíře rektorátu UK).

51 MÚA, fond Výbor prezídia ČSAV (dále VP ČSAV), Zápis z 31. schůze VP ČSAV dne 15. 8. 1956, bod 1. Rodinu V. Votruby v té době tvořili manželka, 18letý syn Jan (stal se rovněž fyzikem, v roce 1982 emigroval do USA) a 13letá dcera Jelena (která vystudovala biologii). Do Dubny s ním odjely manželka a dcera. 
vysloveno přání, aby za členy Vědecké rady SÚJV byli z členských zemí navrhováni z části pracovníci, kteří budou stálými spolupracovníky ústavu. ${ }^{52}$

Následným dopisem z 27. července 1957 požádalo ředitelství SÚJV československou vládu, stejnou (diplomatickou) cestou, o jmenování vládního zmocněnce k podpisu stanov ústavu, tř́ členů Vědecké rady a jednoho člena Finančního výboru SÚJV..$^{53}$

Ustavující zasedání SÚJV a jeho orgánů (Vědecké rady a Finančního výboru) se konala v druhé polovině záríi 1956 již v Dubně, aby se účastníci mohli seznámit s ústavem. Na zasedání zplnomocněných př̌edstavitelů vlád členských zemí SÚJV 20. zárí byly schváleny stanovy ústavu, 24. září se konalo první zasedání Vědecké rady SÚJV a 26. září první zasedání Finančního výboru SÚJV. ${ }^{54}$

Již zmíněným vládním usnesením č. 2038 ze dne 9 . srpna 1956 byli členy Vědecké rady SÚJV za Československo jmenováni V. Votruba, V. Petržílka a Č. Šimáně a členem Finančního výboru SÚJV F. Kovářr. ${ }^{55}$ Protože V. Votruba se na základě schválených stanov SÚJV stal členem Vědecké rady z titulu funkce náměstka ředitele ústavu, byl třetím členem Vědecké rady za Československo dodatečně jmenován F. Kovář (člen Finančního výboru SÚJV, který však byl v zápětí zrušen). ${ }^{56}$ Vedoucím československé delegace vyslané na zářijová ustavující zasedání SÚJV byl usnesením vlády č. 2296 ze dne 14. září 1956 jmenován člen korespondent a zástupce hlavního sekretáře ČSAV Jaroslav Kožešník (vzděláním strojní inženýr a uznávaný odborník v oboru aplikované matematiky a mechaniky), který byl zároveň vládou zmocněn k podpisu stanov SÚJV a př́ípadně i dalších na zasedání přijatých dokumentů. ${ }^{57}$ Funkci československého vládního zmocněnce pro SÚJV zastával pak J. Kožešník až do konce roku 1980; mezi tím se stal v roce 1957 hlavním vědeckým sekretářem ČSAV, 1960 akademikem, 1961 místopředsedou a 1970 předsedou ČSAV. ${ }^{58}$

52 Archiv SÚJV, fond 3/1/21, Переписка с полномочным представителем, Посольством в Москве и научными учреждениями Чехословацкой народной респупблики по вопросам финансирования, объмене кадрами, научных связях, 26. 07. 1956-30. 12. 1956, zn. „OI-168“. Dopis byl podepsán ředitelem Blochincevem a oběma jeho náměstky.

53 Archiv SÚJV, fond 3/1/21, zn. „OI-193“.

54 V korespondenci SÚJV začal být poté použiván hlavičkový papír s emblémem budovy synchrofázotronu Laboratoře vysokých energií v modrém poli a výčtem členských zemí ústavu v národních jazycích. Místo geografické adresy ústavu však bylo nadále uváděno jen číslo poštovní schránky na Moskevské hlavní poště.

55 Jména odborníků nominovaných československou vládou do Vědecké rady a Finančního výboru SÚJV byla tlumočena řediteli Blochincevovi dopisem československého velvyslanectví v Moskvě z 27. července 1956. Připojena byla informace, že V. Votruba odjede z Prahy 1. záŕí t. r. Archiv SÚJV, fond 3/1/21. Dopis Velvyslanectví Československé republiky z 24. 8. 1956, No. 8871/56 (podepsán dočasný pověřenec L. Vacata).

56 Zasedání Vědecké rady SÚJV se vedle členů rady s platným hlasem zpravidla účastnily jako přizvaní nebo delegovaní experti další osoby.

57 Archiv SÚJV, fond 3/1/21, fol. 17. Písemné zmocnění J. Kožešníka (v ruštině) bylo datováno v Praze 18. zář́ 1956 a podepsáno předsedou vlády V. Širokým a ministrem zahraničních věcí V. Davidem.

58 Na rozdíl od řady ostatních členských zemí SÚJV byl československým vládním zmocněncem vrcholný představitel ČSAV, tj. instituce základního výzkumu, nikoli představitel národní autority pro atomovou energii $\mathrm{s}$ širším polem působnosti a zájmů. Takové zastoupení (které vyplynulo ze zrušení VVAE) bezesporu lépe reprezentovalo v preambuli Dohody o zř́zení SÚJV deklarovanou spolupráci př́i teoretických a experimentálních výzkumech jaderné fyziky s cílem rozšíření možností využití atomové energie k mírovým účelům. Nicméně v 60. letech se také J. Kožešník stal členem takové národní autority, a sice nově zřízené Československé komise pro atomovou energii. Vládním zmocněncem SSSR na ustavujícím zasedání SÚJV v záŕí 1956, na němž byly schváleny stanovy SÚJV, byl J. P. Slavskij, vedoucí Hlavní správy pro využití atomové energie při Radě ministrů SSSR (a odborník v oboru metalurgie barevných kovů). V r. 1957 se stal ministrem středního strojírenství SSSR a na postech vedoucího Hlavní správy a vládního zmocněnce v SÚJV ho vystřídal V. S. Jemeljanov (rovněž odborník v oboru metalurgie), který byl v letech 1957-1959 zároveň stálým představitel SSSR v Mezinárodní agentuře pro atomovou energii ve Vídni. 
Uvolnění V. Votruby pro SÚJV, byt' na omezenou dobu, bylo ovšem citelným oslabením výuky teoretické fyziky na Karlově univerzitě. Jeho odjezd do Dubny byl navíc doprovázen smutnou událostí - dne 3. záríi 1956 zemřel profesor V. Trkal (který se však na výuce teoretické fyziky na MFF UK již od školního roku 1953/54 nepodílel, byl z ní „uvolněn“).59

\section{Působení V. Votruby ve funkci náměstka ředitele SÚJV (několik ilustrací)}

V prvních stanovách SÚJV byly upřesněny také otázky volby, kompetencí a povinností ředitelství ústavu. Bylo explicitně stanoveno, že ředitel a jeho dva náměstkové jsou voleni vládními zmocněni (většinou hlasů) z vědců členských zemí ústavu, ředitel ústavu na dobu trř́ let, jeho náměstci na dobu dvou let. $V$ pravomoci ředitele je jednat $s$ př́slušnými institucemi členských zemí o všech otázkách týkajících se činnosti ústavu. Náměstci ředitele ho zastupují ve vedení ústavu a stejně jako on zodpovídají za činnost ústavu. Ředitelství se zodpovídá vládním zmocněncům a pravidelně jim referuje o své práci. Ve své práci se ředitelství ř́dí jen usneseními Finančního výboru a Vědecké rady, nepřijímá žádné (př́ímé) pokyny od vlád členských zemí. Finančnímu výboru předkládá každoročně návrh rozpočtu ústavu a zprávu o jeho plnění. V oblasti vědecké činnosti ředitelství rídí ústav v souladu s plánem vědecko-výzkumných prací a usneseními Vědecké rady. Má právo dílčím způsobem měnit zaměření vědecko-výzkumných prací v jednotlivých laboratořích ústavu, musí však o tom informovat Vědeckou radu. Každoročně předkládá Vědecké radě k posouzení a schválení plány vědecko-výzkumných prací, plány dalšího rozvoje ústavu a zprávu o vědecké činnosti ústavu. $\mathrm{K}$ pravomocím ředitele patřilo také přijímání a uvolňování pracovníků, stanovení jejich platů a př́platků podle príijatých zásad.

Funkce náměstka ředitele SÚJV zahrnovala spoustu vědecko-organizační a administrativní práce, př̌i níž však byly nápomocny administrativní složky ústavu (administrativní ředitel, zahraniční a kádrové oddělení a další). V. Votruba měl jako vědecký náměstek ředitele na starosti agendu zahraničních pracovníků na dlouhodobých pracovních pobytech v SÚJV. Na toto téma referoval na Vědeckých radách ústavu. Hned na prvním zasedání VR SUJV, 26. září 1956, ve svém referátu uvedl, že ředitelství ústavu obdrželo z členských zemí zatím 48 anket (tj. formulářu vyplněných zájemci o práci v ústavu), a sice: 4 (ankety za) Mad’arsko, 2 NDR, 4 ČLR, 11 Polsko, 8 Československo, 10 Rumunsko, 6 KLDR, 3 Mongolsko. $Z$ těchto zájemců o práci v ústavu je 18 teoretiků, 27 experimentátorů, 1 konstruktér a 2 fotochemici, $40 \mathrm{z}$ nich má zájem nastoupit do ústavu ještě v roce 1956. Dodal, že podle dodatečných informací získaných během zasedání Vědecké rady to vypadá, že v roce 1957 přijede do SÚJV dalších 58 zahraničních pracovníků. ${ }^{60}$

Z československých teoretických fyziků nastoupili k dlouhodobému pracovnímu pobytu v SÚJV jako první Ivan Úlehla z Ústavu jaderné fyziky ČSAV61 a Jan Fischer z Fyzikálního

59 Miroslav BrdičKa, - Viktor Trkal, Profesor Viktor Trkal. Pout' moderni fyzikou, Praha 2007, s. 38.

60 MÚA, fond Řízení a správa pracovišt' ČSAV, k. 194, i. č. 485. ОИЯИ. Материалы первого заседания Ученого совета, 24-26 сентября 1956.

61 I. Úlehla (1921-2004) nastoupil na roční pracovní pobyt v SÚJV v listopadu 1956, jako vůbec první československý pracovník. Vstupní anketu vyplnil již 25. srpna t. r.; jako předmět svého odborného zájmu uvedl kvantovou teorii pole. V SÚJV byl zařazen jako „starší vědecký pracovník“ do Laboratoře teoretické fyziky, která se ovšem teprve konstituovala. Do Dubny za ním přijela manželka s pětiletým synem. Z pobytu vzešla mj. práce I. Úlehly o teorii mezonu $\mu$. Do SÚJV se vrátil k druhému dlouhodobému pobytu v listopadu 1963 . V té době 
ústavu ČSAV.62 V lednu 1957 nastoupili do SÚJV fyzik-elektronik Antonín Kokeš a elektroinženýr Jiří Doležal. V červnu 1957 dorazilo dalších 11 československých pracovníků (fyziků, chemiků, inženýrů i techniků-středoškoláků), vesměs z tehdejšího Ústavu jaderné fyziky ČSAV: František Bradna, Milan Čihák, Tomáš Fukátko, Josef Habanec, Bohumil Chalupa, Miroslav Karmasin, Mikuláš Kuzmiak, Břetislav Malý, Miloslav Marek, Antonín Prokeš a Josef Šinágl. V referátu O práci vědeckých pracovnikủ príjiždějicich ze zahraničí, který V. Votruba přednesl na 5. zasedání Vědecké rady SÚJV (která se konala ve dnech 14.-17. ledna 1959 a byla poslední, jíž se účastnil ve funkci náměstka ředitele ústavu), konstatoval, že v ústavu toho času pracuje 116 zahraničních pracovníků. V přehledu podle jednotlivých členských zemí bylo tehdy Československo zastoupeno 17 pracovníky, což představovalo (po 25 pracovnících z Rumunska) druhou nejpočetnější národní skupinu. ${ }^{63}$

Dubnu a SÚJV navštívili v rámci exkursí zájemci a pracovníci dalších oborů z Československa. Např́íklad dopisem z 3. dubna 1957 se obrátil na ředitele Blochinceva F. Kováŕ z československého velvyslanectví v Moskvě se žádostí o povolení návštěvy SÚJV skupině československých lékařu a odborníků jaderného průmyslu vysokých energií (!). Uvedl, že o exkursi již jednal s náměstkem Votrubou, který mu sdělil, že exkurse se konají vždy v pátek. Navrhl proto datum 12. dubna t. r. a připojil jména účastníků exkurse: Vratislav Havlovic (Fyzikální ústav Lékařské fakulty UK v Plzni), Archimiro Caga (Onkologický ústav v Brně), Bohumil Vavrejn (Ústav klinické a experimentální chirurgie, Praha), Josef Fuksa (Hlavní správa jaderné energie v Ministerstvu energetiky ČSR, Praha), Josef Kuba (ČKD-Stalingrad, Praha), Vratislav Rýpar (Ministerstvo chemického průmyslu ČSR, Praha; jméno bylo dodatečně škrtnuto), Vladimir Sedláček (Ministerstvo hutí a rudných dolů ČSR, Praha, dodatečně změněno na Jaroslav Staníček). Jak dokládá červený prŕípis na došlém dopise, exkurse byla povolena. ${ }^{64}$

Působnost $V$. Votruby ve funkci náměstka ředitele SÚJV přispěla také $\mathrm{k}$ domluvě a realizaci prvních československých dodávek elektroniky, ofsetových tiskařských strojů (Vetaprint-30 s kovolisty), ${ }^{65}$ automobilů a nábytku pro SÚJV; na mnohé korespondenci o těchto otázkách byl Votruba podepsán. Jako náměstek ředitele SÚJV byl Votruba spolupodepsán také např. na dopise velvyslanci Vošahlíkovi z 24. listopadu 1956, kterým ředitelství SÚJV urgovalo doplatek československého členského př́spěvku na financování ústavu v roce

byl již pracovníkem Fakulty technické a jaderné fyziky ČVUT. Spolu s ním tehdy nastoupili k dlouhodobým pobytům v SÚJV další tři teoretičtí fyzikové z téže fakulty, a sice Jiř́i Blank, Zdeněk Pluhař a Jiř́ Tolar. Od března 1964 do července 1967 I. Úlehla zastával post náměstka ředitele SÚJV, jako druhý z Československa. Archiv SÚJV, Osobní složky zahraničních pracovníků SÚJV, Československo, Úlehla Ivan.

62 Jan Fischer (nar. 1932) nastoupil k původně ročnímu pobytu v SÚJV v květnu 1957, aby zde pod vedením profesora Votruby dokončil aspiranturu. V SÚJV pak pracoval až do listopadu 1961 (mezi tím se v Československu oženil). Z pobytu vzešla série prací o studiu amplitudy rozptylu pomocí dispersních vztahů, na kterých spolupracoval zčásti s rumunským teoretickým fyzikem S. Ciulli. Archiv SÚJV, Osobní složky zahraničních pracovníků SÚJV, Československo, Fischer Jan.

63 Interní tisk SÚJV Материаль пятой сессии Ученого совета ОИЯИ, Дубна 1959, s. 6-8.

64 Archiv SÚJV, fond 3/1/44, fol. 48 (dopis na hl. papíře Velvyslanectví Československé republiky v Moskvě, zn. „M-1671/57“", 3. 4. 1957).

65 Dodání dvou tiskařských (kopírovacích) strojů Vetaprint-30 firmy KOVO Spojenému ústavu jaderných výzkumů přislíbil prezident A. Zápotocký během návštěvy ústavu v lednu 1957 (viz dále v textu). S odkazem na tento př́íslib se náměstek ředitele SÚJV V. Votruba obrátil dopisem z 20. ledna 1957 na tehdejšího ministra československého zahraničního obchodu Dvořáka a požádal ho o pomoc s realizací dodávky. Tiskařské a kopírovací stroje byly tehdy ostře sledovanou technikou. Archiv SÚJV, fond 3/1/44: Переписка с Полномочным представителем, Посольством..., 3. 01. 1957-31. 12. 1957, zn. „ОI-407“. 
1956. Československý příspěvek SÚJV pro (neúplný) rok 1956 byl stanoven ve výši 4877100 rublů, z toho mělo být uhrazeno ve valutě SSSR 4848974 rublů a v zahraniční valutě podle kursu Státní banky SSSR 28126 rublů. ${ }^{66}$

V. Votruba byl také spolupodepsán na telegramu, kterým ředitelství SÚJV počátkem dubna 1957 informovalo členy Vědecké rady o úspěšném spuštění sychrofázotronu Laboratoře vysokých energií, při kterém bylo dosaženo energie protonů $8,3 \mathrm{GeV}$. Do Československa byl tento telegram zaslán souběžně Č. Šimáňovi a V. Petržilkovi dne 9. dubna 1957. ${ }^{67}$

Jako náměstek ředitele SÚJV se V. Votruba zúčastnil také několika významných zahraničních konferencí. V roce 1957 byl vyslán jako „pozorovatel“ za SÚJV na První generální konferenci Mezinárodní agentury pro atomovou energii ve Vídni. Jako člen delegace SÚJV se zúčastnil také tř́ (sedmé až deváté) mezinárodních konferencí o fyzice vysokých energií, známých pod historickým názvem Rochesterské. Šlo o vrcholné konference v oboru, pořádané od roku 1950 (a konané zpočátku v USA). Počet účastníků těchto konferencí byl omezený a účast vázána na pozvání ze strany organizátorů. Sedmá konference se konala 15.-19. dubna 1957 v Rochesteru v USA; účast V. Votruby na konferenci schválil Výbor prezídia ČSAV ve schůzi 20. prosince 1956, na základě doporučení ředitele SÚJV Blochinceva a s podmínkou, že SÚJV ponese $\mathrm{s}$ tím spojené finanční náklady. ${ }^{68}$ Osmá konference se konala 29. června - 5. července 1958 v Ženevě ve Švýcarsku (poprvé mimo území USA), a to pod patronátem CERN a s podporou Mezinárodní unie pro čistou a aplikovanou fyziku (IUPAP). Delegaci SÚJV na konferenci tvořili: N. N. Bogoljubov (zakladatel a první ředitel Laboratoře teoretické fyziky, vedoucí delegace), ředitel SÚJV D. I. Blochincev a oba jeho náměstci M. Danysz a V. Votruba, dále I. V. Čuvilo (náměstek ředitele Laboratoře vysokých energií), L. I. Lapidus (vedoucí vědecký pracovník Laboratoře jaderných problémů) a H. Pose (německý fyzik působící od roku 1945 v Sovětském svazu, v letech 1956-1959 pracovník Laboratoře jaderných problémů). Konference se účastnilo i několik dalších sovětských fyziků, např. I. J. Tamm z Moskevské Lomonosovovy univerzity. ${ }^{69}$ Jako československý delegát se konference zúčastnil také V. Petržílka.

Osmá Rochesterská konference byla důležitým mezníkem v navazování kontaktů mezi SÚJV a CERN. Konferenci předsedal ředitel CERN profesor C. J. Bakker. Zasedání se konala ve Fyzikálním ústavu Lékařské fakulty Ženevské univerzity. Dne 3. července odpoledne byla uspořádána prohlídka laboratoří CERN v Meyrinu u Ženevy, kde se stavěl synchrotron pro energie $25 \mathrm{GeV}$. Konference byla zakončena 5. července odpoledne projevem amerického fyzika R. Oppenheimera a společnou večeř́i. V. Petržílka a V. Votruba se hned 6. července společně letecky vrátili do Prahy. Referáty, přihlášené na konferenci, nebyly přednášeny jednotlivě, nýbrž shrnuty v několika souhrnných referátech a koreferátech, které přednesli jako ,zpravodajové“ přední odborníci v př́slušném oboru. V. Petržílka v cestovní zprávě uvedl, že na konferenci byly zmíněny také práce československých fyziků: profesor O. Piccioni z Radiation Laboratory v Berkeley se zmínil o výsledcích společné

66 Archiv SÚJV, fond 3/1/21, zn. „OI-1841“ (kopie).

67 Archiv SÚJV, fond 3/1/44, zn. „N 1648/29“.

68 MÚA, fond Zápisy ze schůzí VP ČSAV, k. 7, 50. schůze Výboru prezídia ČSAV dne 20. 12. 1956, bod 33. Návrhủm ředitelství SÚJV na vyslání československých vědeckých pracovníkủ do zahraničí (na náklady SÚJV) bylo ze strany československých orgánů většinou vyhověno. Vyslání do zahraničí pracovníkủ SÚJV, kteří byli občany SSSR, bylo oproti tomu komplikovanější.

69 Bruno FerRetTi (ed.), 1958 Annual International Conference on High Energy Physics at CERN. Proceedings, Genève 1958 (dostupné <https://cds.cern.ch/record/108580/files/C58-06-30-entire.pdf>, ověřeno 7. 3. 2021). 
práce československé a polské skupiny kosmického záření, zejména o dvoucentrovém modelu (jehož spoluautorem byl J. Pernegr); profesor B. d'Espagnat z CERN zmínil práci V. Votruby a M. Lokajíčka o klasifikaci elementárních částic na základě izospinu. ${ }^{70}$

Devátá Rochesterská konference se konala 15.-25. července 1959 v Sovětském svazu v Kyjevě, opět pod záštitou IUPAP. Spoluorganizátorem konference byl SÚJV, který byl na konferenci také mohutně zastoupen. Této konference, která se ovšem připravovala s velkým časovým předstihem, se V. Votruba zúčastnil již jen jako vědecký pracovník SÚJV (funkci náměstka ředitele SÚJV předal v březnu toho roku svému nástupci). $\mathrm{K}$ účasti na konferenci byl oficiálně pozván jménem organizačního výboru dopisem ředitele Blochinceva z 15. června 1959 a požádán, aby předsedal plenárnímu zasedání konference o otázkách dispersních vztahů. ${ }^{71} \mathrm{Z}$ československých fyziků se této konference zúčastnil také např. Josef Kvasnica, který byl vyslán Fakultou technické a jaderné fyziky ČVUT (na místo původně navrženého Luboše Valenty, který musel nastoupit na vojenské cvičení).

Z pověrení ředitele D. I. Blochinceva zastupovali V. Votruba spolu s M. Danyszem SÚJV také např. na slavnostním spuštění prvního polského experimentálního reaktoru EWA (dodaného Sovětským svazem) v Ústavu jaderných výzkumů v Otwocku u Varšavy dne 14. června 1958.72

V době působení V. Votruby ve funkci náměstka ředitele SÚJV byly dojednány také návštěvy a dlouhodobé pobyty prvních sovětských pracovníků SÚJV v Československu. Konkrétně dopisem ze 14. února 1957 se V. Votruba jako náměstek ředitele SÚJV obrátil (rusky) na ředitele Výzkumného ústavu pro vakuovou elektrotechniku v Praze-Hloubětíně J. Váňu se žádostí, zda by mohli přijmout na jedno- až dvouměsiční stáž do oddělení urychlovačů pracovníka SÚJV, občana SSSR V. V. Kol'gu. Náklady spojené s pobytem přebíral SÚJV. Žádost byla uvedena slovy (překlad z ruštiny): „Ředitelství Spojeného ústavu jaderných výzkumů přikládá velký význam tomu, aby pracovníci Ústavu měli možnost seznámit se s vědeckými problémy, metodikou jejich řešení a také podmínkami práce v jiných vědecko-výzkumných ústavech, zejména zahraničních." Dále pak bylo upřesněno, že V. V. Kol'ga je 29letý pracovník sektoru urychlovačů v Laboratoři jaderných problémů (LJaP) a pracuje na zhruba stejných otázkách, kterými se ve VÚVET zabývá Jiří Teichman pod vedením M. Seidla. ${ }^{73}$ Během stáže V. V. Kol'gy ve VÚVET projevil

70 MÚA, fond Sbírka cestovních zpráv, Švýcarsko, 1953-1958. V. Petržílka, Zpráva o účasti na Mezinárodní konferenci pro fyziku částic vysokých energií v CERNu od neděle 29. června do soboty 5. července 1958, pořádané pod záštitou Mezinárodní unie pro čistou a aplikovanou fyziku (datováno 21. 12. 1958). RNDr. M. Lokajíček, DrSc. v rozhovoru s E. Těšínskou ze dne 15. července 2015 ke spolupráci s V. Votrubou a prezentaci jejich společné práce na zmíněné konferenci uvedl: „... na podzim 1957 jsme s Votrubou udělali další práci, kterou jsme systematiku elementárních částic posunuli zas o třídu dál. Vyšlo to však jenom jako preprint v Dubně, i když bylo domluveno, že to bude publikováno v Nuclear Physics. Votruba tuto práci prezentoval v roce 1958 na VIII. Rochesterské konferenci, která se konala v Ženevě. Práce vzbudila zájem. Francouzský fyzik Bernard d'Espagnat, který patřil k vrcholným představitelům oboru, tehdy Votrubu vyzval, aby zůstal v Ženevě o týden déle a o naší práci podrobně referoval na semináři, který d'Espagnat zorganizuje. Votruba si však nemohl dovolit přetáhnout povolenou dobu zahraničního pobytu a musel se vrátit. Tím nemohl d’Espagnatovi a tamním teoretikům naši koncepci vysvětlit..." (podle záznamu rozhovoru pořízeného E. Těšínskou).

71 Archiv SÚJV, fond 4/1/124, zn. „Иcx. No. 252/59“.

72 Archiv SÚJV, fond 3/1/84: Переписка с Полномочным представителем, Посольством..., 6. 01. $1958-31$. 12. 1958, zn. „Иcx. No. 365/29“ (telegram D. I. Blochinceva J. Kožešníkovi z 11. 6. 1958, pověřující V. Votrubu zastupováním SÚJV na zmíněné akci).

73 Archiv SÚJV, fond 3/1/44: Переписка с Полномочным представителем, Посольством..., 3. $01.1957-$ 31. 12. 1957, zn. Исх. No. 681/29“. 
zájem o návštěvu tohoto ústavu také vedoucí sektoru urychlovačů v LJaP J. N. Děnisov. J. Váňa však v odpovědi z 9. dubna 1957 adresované V. Votrubovi (opět rusky) napsal, že by uvítal, kdyby Děnisov mohl přijet do ústavu až po odjezdu Kol'gy, nebot' současný pobyt obou pracovníků v ústavu by toho roku působil prostorové obtíže. Zároveň vyslovil obavu, že pobyt ve VÚVET nebude mít pro Děnisova žádný význam, protože výkonnými zesilovači se v ústavu nikdo nezabývá. Uskutečnění stáže ponechal nicméně na uvážení Votruby a ředitele Laboratoře jaderných problémů SÚJV V. P. Dželepova. Zdá se, že k této stáži nedošlo. ${ }^{74}$

Do Československa byl v roce 1957 pozván také ředitel SÚJV D. I. Blochincev, a sice k účasti na Mezinárodní vědecké konferenci ČVUT v Praze u př́ležitosti výročí 250 let od založení inženýrské školy v Praze. Konference se konala ve dnech 28.-30. května 1957. Pozvání k účasti na konferenci a týdennímu pobytu v Československu (spolu s manželkou) mu bylo zasláno jménem tehdejšího rektora ČVUT akademika Theodora Ježdíka. ${ }^{75}$ $\mathrm{Na}$ zahájení konference Blochincev přednesl referát Atomová energetika z pohledu fyziky (rusky). Při př́ležitosti konference mu byl na ČVUT také udělen čestný doktorát technických věd. Do Prahy mu tehdy bylo tlumočeno také pozvání předsedy Polské Státní rady pro atomovou energii a vládního zmocněnce v SÚJV W. Biliga, aby se při zpáteční cestě zastavil ve Varšavě, k projednání některých otázek společného zájmu (řečeno jazykem diplomacie). ${ }^{76}$

\section{Návštěva prezidenta A. Zápotockého v SÚJV}

Jako náměstek ředitele SÚJV se V. Votruba účastnil také četných oficiálních přijetí významných hostů ústavu a nejrůznějších delegací. Jako pro fyzika pro něho byly jistě nejzajímavější návštěvy významných vědců. Ve prospěch vědy a lidských osudů však bylo možno občas využít i návštěv vládních a politických činitelů.

Necelý rok po zřízení ústavu, v lednu 1957 navštívila SÚJV československá vládní a stranická delegace $\mathrm{v}$ čele s prezidentem Antonínem Zápotockým, která byla na oficiální týdenní návštěvě v Sovětském svazu. Přesněji řečeno, SÚJV tehdy navštívila jedna část delegace, druhá část odletěla na exkursi do Sverdlovska. Návštěvy Dubny se tehdy zúčastnil také první tajemník ÚV KSČ A. Novotný a V. Kopecký (kteří stáli na samém počátku přizvání Československa k účasti a zř́zení ústavu v lednu 1956) a československý velvyslanec v SSSR J. Vošahlík. Př́tomni byli také zástupci tisku včetně ČTK (návštěva je dokumentována sérií pamětních fotografií). V. Votruba spolu s ředitelem Blochincevem delegaci v ústavu uvítali a spolu s dalšími vedoucími pracovníky ústavu ji doprovázeli při prohlídce areálu a velkých experimentálních zařízení.

Návštěva ústavu na prezidenta Zápotockého zřejmě dobře zapůsobila a zmínil se o ní v závěrečném proslovu v Moskvě. V kontextu slov o československo-sovětské spolupráci ve využití jaderné energie uvedl (podle dochovaného konceptu): „O výsledcích této vzájemné spolupráce presvědčila se naše delegace při návštěvě Spojeného ústavu jaderného

74 Tamtéž, fol. 61 (dopis na hlavičkovém papíře VÚVET, bez registračního čísla).

75 Tamtéž, fol. 44 (dopis Rektora ČVUT v Praze akademika T. Ježdíka, 5. 3. 1957, bez registračního čísla).

76 Tamtéž, zn. „No. 2600/29“, fol. 64 a 65 (kopie telegramu zaslaného D. I. Blochincevovi 30. 5.1957 do hotelu Praha administrativním ředitelem SÚJV M. Lebeděnkem). 
výzkumu. Uvědomili jsme si tam, že pro malou zemi, jako jsme my, by bylo nanejvýš obtižné a vlastně vůbec nemožné vybudovat tak nákladná a velkorysá zařizení vlastními silami." "77

V. Votruba tehdy využil osobního setkání s prezidentem Zápotockým k připomenutí a zopakování žádosti o propuštění z vězení svého bývalého aspiranta Miloše Lokajíčka.

Miloš Lokajíček (1923-2019) patřil ke generaci, jejíž studia byla přerušena druhou světovou válkou. Maturoval v roce 1942 a teprve po válce pokračoval ve studiu matematiky a fyziky na Př́rodovědecké fakultě UK. Vysokoškolské studium završil v roce 1949 státními zkouškami a v červnu 1950 doktorátem přírodních věd. Již v doktorské disertaci O transformačnich vlastnostech rozšiřené soustavy Maxwellových rovnic navázal na disertační práci V. Votruby. Po absolvování fakulty byl zprvu zaměstnán jako fyzik-radiolog v resortu ministerstva zdravotnictví: v dubnu 1949 nastoupil do Státního radiologického ústavu a od října 1949 přešel do Radioterapeutického ústavu při nemocnici v Praze na Vinohradech. Od 1. prosince 1950 byl prrijat na vědeckou aspiranturu v oboru fyziky na Př́rodovědecké fakultě UK. Jeho školitelem se stal V. Votruba. Společně pracovali na teorii klasifikace elementárních částic na základě izotopického spinu; výsledkem byly dvě cizojazyčné publikace. ${ }^{78}$ Spolu s fyzikou je sbližovaly i jejich světonázorové postoje. Po ukončení aspirantury, od 1. prosince 1953 M. Lokajíček nastoupil jako vědecký pracovník do Laboratoře pro nukleární fyziku ČSAV, jejiž vedení v té době právě převzal Č. Šimáně po V. Petržílkovi a která se od 1. ledna 1954 stala oddělením nově zřízeného Fyzikálního ústavu ČSAV.

V únoru 1954 byl však M. Lokajíček zatčen a v červnu t. r. odsouzen $\mathrm{k}$ trestu odnětí svobody na dobu sedmi let „pro velezradu za členství a účast na schůzkách organizace 'Rodina' zaméřující se na náboženskou výchovu mládeže. “79 $\mathrm{V}$ téže kauze bylo tehdy odsouzeno šest osob. M. Lokajíček byl v té době již otcem tř́ nezletilých dětí a jeho rodina zůstala prakticky bez finančních prostředků. Vzhledem k zatčení a odsouzení byl propuštěn z Fyzikálního ústavu ČSAV.

Se žádostí o prezidentskou milost pro syna se na manželku prezidenta Marii Zápotockou v roce 1954, hned po vynesení rozsudku, obrátila matka M. Lokajíčka. Ve věci M. Lokajíčka se v Kanceláři prezidenta republiky, ještě před vynesením rozsudku, „dotazovali““ také hlavní sekretář ČSAV akademik František Šorm a fyzikální chemik akademik Rudolf Brdička. V. Votruba se obrátil na prezidenta Zápotockého ve věci M. Lokajička poprvé dopisem z 10. ledna 1955, v němž s velkou naléhavostí uvedl:

77 NA, fond ÚV KSČ 1945-1989, A. Zápotocký, sv. 35, a. j. 1034. Koncept projevu A. Zápotockého v Moskvě 31. 1. 1957.

78 Václav Votruba - Miloš LoKaJ́ǐčE, Unified description of leptons, Physical Review 86, April 1952, s. 260 (předloženo k publikaci 3. 1. 1952); тíž, On isotopic spin of elementary particles, Czechoslovak Journal of Physics 2, 1953, s. 1-8.

79 Šlo o skupinu osob kolem chorvatského kněze S. T. Kolakoviče. Provinění M. Lokajíčka bylo v úředních spisech formulováno slovy: „Odsouzený zapojil se v r. 1948 do protistátní organisace 'Rodina', která byla založena a řízena Vatikánem prostřednictvím pověstného Kolakoviče. Jejím cílem bylo zejména organisovat protistátní výchovu nábožensky založené mládeže. Do r. 1953 účastnil se odsouzený různých schůzek této organisace a to i schůzky v Litoměřicích v polovině r. 1948, kde bylo dohodnuto, že činnost organisace se zaměří na získávání dělnické mládeže pro protistátní činnost. Koncem r. 1952 účastnil se schůzky, kde členy organisace instruoval zrádný kněz a agent Vatikánu Štefan Naholka. Pro schůzky 'Rodiny’ propůjčoval odsouzený i svůj byt.“ Archiv Kanceláře prezidenta republiky, Praha (dále AKPR), fond Protokol T (tajné) 1945-1963, sign. 0 3008/58, Lokajíček Miloš, trestní př́ípad, 1955-1957. Dr. Viktor Knapp, Informace pro soudruha prezidenta republiky v trestní věci Miloše Lokajíčka, 8. 4. 1955 (citace ze zprávy ministerstva spravedlnosti). 
„Vážený pane prezidente,

dovoluji si Vás požádati o slyšeni ve věci Miloše Lokajička, mého bývalého aspiranta a bezpochyby nejnadanějšího z našich mladých pracovníků v nukleárni fysice, který byl odsouzen pro členství v rozpuštěném katolickém spolku 'Rodina'. Chtěl bych Vás při tom, pane presidente, informovat o mezinárodním postavení československé nukleární fysiky, zvláště teoretické, jejím mimořádném významu pro mezinárodní prestyž(!) našeho státu a o tom, jakou škodu a ztrátu nám v tomto ohledu pi̊sobí vyřazení M. Lokajičcka z odborné činnosti a mezinárodni soutěže; osobně pocituji tuto ztrátu zvláště po zkušenostech ze svého pobytu v NDR a Mad'arsku. Nakonec bych Vás chtěl poprosit, abyste jmenovanému nějak umožnil pokračovat v slibně započaté vědecké práci ku prospěchu naši vlasti.“80

$\mathrm{Na}$ dopise, doručeném prezidentské kanceláři, byl červenou tužkou připsán pokyn A. Zápotockého k přešetření záležitosti. Profesoru Votrubovi však audience udělena nebyla. Dopisem Kanceláře prezidenta republiky z 8. února 1955 mu bylo s politováním sděleno, že prezident ho nemůže pozvat k osobní rozmluvě, ,nebot' jeho čas je zcela vyplněn neodkladnými úkoly.

O věci Miloše Lokajička byl však president republiky již dř́ve informován z podnětu žádostí o milost, které byly ve prospěch Miloše Lokajička podány.

Na pokyn presidenta republiky jsme na základě těchto dř́vějšich žádostí již dali podnèt $k$ provedeni zákonem předepsaného řizení. Toto řizeni se provádí, dosud neni skončeno. Ujištujeme Vás, vážený pane profesore, že v tomto řizení bude vzat zřetel ke všem důležitým okolnostem prípadu i k těm, které uvádíte ve svém dopise ze dne 10. ledna 1955.“81

Jak vyplývá z prŕíslušného spisu Kanceláře prezidenta republiky, v řízení o milost byla tehdy uplatněna výhrada rozhodnutí prezidenta republiky. Vzhledem k odpykání do té doby př́liš krátké části trestu M. Lokajičkem však bylo uplatnění této výhrady na pokyn prezidenta zrušeno.

Při osobním setkání s prezidentem Zápotockým v lednu 1957 „v Moskvě“ V. Votruba na případ M. Lokajíčka znovu upozornil. K dřívější argumentaci dodal, že Lokajíček bude mít v polovině srpna t. r. odpykanou již polovinu trestu, ve výkonu trestu se řádně chová a pracuje. Prezident dal údajně hned při rozmluvě ,,v Moskvě“ pokyn k novému přešetření záležitosti. Kancelář prezidenta republiky požádala Ministerstvo spravedlnosti o nové přešetření případu a dodatečně i o prošetření trestní věci v př́ípadě ostatních odsouzených $\mathrm{v}$ téže kauze. Milost však byla udělena jen M. Lokajíčkovi, „u něhož bylo prìhlédnuto zejména $k$ jeho odborným znalostem na úseku jaderné fyziky, které mohou být pro naši vědu značným prínosem. U ostatnich spoluodsouzených zvláštního zřetele hodných důvodů pro udělení milosti u nich zjištěno nebylo, a proto jejich žádosti [...] byly postupně zamitnuty." 82

V červnu 1957 byl M. Lokajíček z vězení propuštěn. Jeho první kroky zamírily domů a odtud za Jaroslavem Pernegrem, který byl po dobu Lokajíčkova zatčení v kontaktu $\mathrm{s}$ jeho rodinou. Přestože udělení prezidentské milosti bylo odůvodněno velkou důležitostí

\footnotetext{
80 AKPR, fond Protokol T 1945-1963, spis č. 101.047/55. Dopis V. Votruby prezidentu A. Zápotockému z 10.1. 1955 (napsáno na hlavičkovém papíře Katedry atomistiky na Karlově univerzitě), fotoreprodukce viz obr. 3.

81 AKPR, fond Protokol T 1945-1963, spis č. 1085/55. Kopie odpovědi Kanceláře prezidenta republiky V. Votrubovi z 8. 2. 1955, čj. 103.121/55, podepsán Dr. Viktor Knapp.

82 AKPR, fond Protokol T 1945-1963, spis č. T 1542/57. Ministerstvo spravedlnosti v Praze Kanceláři presidenta republiky, 10. 7. 1957, čj. Mil 4354/57.
} 
M. Lokajíčka pro československou jadernou fyziku, z rozhodnutí stranických orgánů mu nebylo dovoleno pokračovat ve vědecké práci v ČSAV (o působení na vysoké škole nemluvě). Na paradox vyvstalé situace upozornil Kancelář prezidenta republiky dokonce ministr informací V. Kopecký (bývalý předseda VVAE)! Žádná př́mluva však tentokrát nepomohla. M. Lokajíček musil po propuštění z vězení odpracovat nejprve jeden rok jako dělník v podniku Regula v Praze Holešovicích. Od června 1959 byl pak zaměstnán ve fyzikálním oddělení resortního Výzkumného ústavu přístrojů jaderné techniky v Přemyšlení ( $v$ té době začleněného do $n$. p. Tesla). Neformální spolupráci v teoretické fyzice $\mathrm{s} \mathrm{V}$. Votrubou navázal nicméně hned po návratu z vězení; jako teoretičtí fyzici si vystačili víceméně s tužkou a papírem. Výsledky další společné práce o systematice elementárních částic však směli publikovat jen jako preprint SÚJV. ${ }^{83}$ Jako fyzik M. Lokajíček nadále externě spolupracoval také s Radiologickou klinikou UK, profesorem V. Staškem; z této spolupráce vzešla v letech 1958-1961 desítka publikací v československých i zahraničních odborných časopisech.

K vědecké práci v oboru základního výzkumu se $\mathrm{M}$. Lokajíček mohl oficiálně vrátit až v druhé polovině 60. let. Výnosem obvodního soudu pro Prahu 5 ze dne 5. června 1964 byl jeho rozsudek zrušen a zcela zahlazen. $V$ roce 1966 mu byla udělena vědecká hodnost kandidáta fyzikálně-matematických věd na základě obhajoby práce $\mathrm{v}$ oboru experimentální fyzika; obhajoba se konala na Fakultě technické a jaderné fyziky ČVUT 23. května 1966. Propustkou pro návrat M. Lokajíčka do Fyzikálního ústavu ČSAV byl roční pracovní pobyt v SÚJV, na který byl vyslán v březnu 1968 jako zaměstnanec VÚPJT (anketu SÚJV vyplnil již 5. května 1967). V SÚJV pracoval v teoretickém oddělení Laboratoře vysokých energií. Původní záměr byl (a přijetí M. Lokajíčka do SÚJV bylo schváleno s poznámkou), že zde budou pracovat spolu s profesorem Votrubou; ten však od plánu odjet do SÚJV na roční pracovní pobyt odstoupil. Po návratu z Dubny, od dubna 1969 nastoupil M. Lokajíček jako vědecký pracovník do Fyzikálního ústavu ČSAV. ${ }^{84}$ Vědecky pracoval takřka do posledních dnů svého života, spolupracoval se SÚJV i CERN. Zemřel 7. listopadu 2019 ve věku 96 let.

83 V. Votruba - Miloš Lokajíček, An Algebraic System of Fundametal Particles, Preprint JINR-Dubna P-181, June 1958.

84 Ve věci opětovného přijetí M. Lokajíčka do Fyzikálního ústavu ČSAV se dopisem z 24. září 1968 obrátil ředitel Fyzikálního ústavu ČSAV L. Pekárek na hlavního vědeckého sekretáře ČSAV J. Pluhaře. Uvedl, že v souvislosti s probíhajícím rehabilitačním řízením v ČSAV obdržel žádost M. Lokajíčka o znovupřijetí do ústavu. Poukázal na zrušení a zahlazení dřivějšího rozsudku nad M. Lokajíčkem a dodal: „Přes značně nepříznivé okolnosti Dr. Lokajíček pokračoval ve své vědecké činnosti a jeho současná vysoká odborná úroveň by byla značným př́nosem pro oddělení fysiky vysokých energií FÚ ČSAV. Domnívám se, že nejlepším vyjádřením morální satisfakce Dr. Lokajíčkovi by bylo umožnění jeho návratu do ČSAV, a žádám proto, aby k tomuto účelu bylo FÚ ČSAV přiděleno mimořádně systemizované místo vedoucího vědeckého pracovníka od 1. 1. 1969. K podobnému závěru dospěla i Rehabilitační komise FÚ ČSAV, která se tímto př́ípadem zabývala, o čemž informovala Ústřední rehabilitační komisi ČSAV dopisem ze dne 8. 8. 1968.“ Dále ještě dodal, že Lokajíček je zaměstnancem n. p. Tesla, Výzkumný ústav př́strojů jaderné techniky v Přemyšlení u Prahy a v současné době pracuje v SÚJV jako vědecký pracovník, odkud se má vrátit koncem roku. Dopisem z 1. listopadu 1968 pak ředitel Pekárek informoval M. Lokajíčka do Dubny, že od 1. ledna 1969 ho přijímají do pracovního poměru jako vědeckého pracovníka do oddělení fyziky vysokých energií FÚ ČSAV. MÚA, fond Fyzikální ústav ČSAV 1953-1978, k. 6, sign. 04 (Nábor pracovních sil). 


\section{Završení výkonu funkce náměstka ředitele SÚJV V. Votrubou a jeho návrat $z$ Dubny}

Dvouleté funkční období náměstků ředitele SÚJV V. Votruby a M. Danysze končilo v březnu 1958. Návrh na nové obsazení postů měla připravit Vědecká rada ústavu a schválit Sbor vládních zmocněnců na svém druhém zasedání v listopadu 1957. Otázka byla projednána na 3. zasedání Vědecké rady SÚJV v září 1957. Protože se oba náměstci ředitele ve svých funkcích osvědčili, bylo navrženo potvrdit je ve funkcích i na další funkční období. V. Votruba však znovu kandidovat nechtěl; jaký byl postoj M. Danysze, není z využitých písemných pramenů jasné. Votruba odůvodňoval svi̊j postoj tím, že v důsledku úmrtí profesorů V. Trkala a Z. Matyáše (1. června 1957) je potřebný pro zajištění výuky teoretické fyziky na Karlově univerzitě. ${ }^{85} \mathrm{~K}$ návratu do vlasti měl V. Votruba také rodinné důvody jeho dcera skončila v Dubně základní školní docházku a v dalším studiu měla pokračovat v Československu, kam s ní měla odjet i matka; v Dubně by tudíž zůstal bez rodiny, což se mu jevilo „velmi obtížně zvládnutelné“. ${ }^{86}$ Chtěl nicméně zůstat v Dubně do června 1958, ale již jen jako vědecký pracovník.

Výbor prezídia ČSAV podpořil žádost Votruby o propuštění z funkce náměstka ředitele SÚJV v usnesení ze schůze 6. listopadu 1957, kde výbor důrazně trval na návratu Votruby do Československa. ${ }^{87}$ Do zasedání Sboru vládních zmocněnců, svolaného na 25.-26. listopadu 1957, se však nepodařilo připravit jiný návrh na obsazení postů náměstkư ředitele, a Vědecká rada SÚJV tudíž požádala Sbor vládních zmocněnců o prodloužení funkčního období stávajících náměstků o jeden rok. Otázka přišla na pořad poslední den zasedání 26. listopadu. Československé stanovisko podporující návrat V. Votruby zde tlumočil J. Kožešník. Votruba vysvětlil své důvody v diskusi; část přítomných je uznala, jiní se ho snažili pochvalnými slovy přemluvit. Rozhodujícím se stalo stanovisko sovětského vládního zmocněnce V. S. Jemeljanova, který uvedl, že důvody Votruby chápe, apeloval však na povinnost vědce v první linii přinášet oběti, a to i s ohledem na politický význam SÚJV. ${ }^{88}$

Sbor vládních zmocněnců nakonec (jednomyslně) schválil řešení, kterým bylo oběma náměstkům ředitele funkční období prodlouženo o jeden rok, tj. do března 1959, a Vědecké radě ústavu uloženo, aby příštímu zasedání Sboru vládních zmocněnců v listopadu 1958 předložila nové návrhy na obsazení obou postů, a také návrh na obsazení postu ředitele (jehož funkční období bylo tříleté). ${ }^{89}$

85 Na Univerzitě Karlově, Matematicko-fyzikální fakultě UK (kde byla v roce 1956 zř́zena katedra teoretické fyziky, jejímž vedoucím byl jmenován Z. Matyáš) působili v té době jako docenti teoretické fyziky Miloslav Brdička (1913-2007), habilitovaný v r. 1954 (od r. 1958 vedoucí katedry teoretické fyziky po Z. Matyášovi) a Čestmír Muzikář (1924-1966), habilitovaný v r. 1958. Na FTJF UK byl obor teoretická fyzika zastoupen pouze profesorem V. Votrubou, který však byl od zář́ 1956 v Dubně a jeho výuka musila být suplována; katedra teoretické fyziky zde zatím zřízena nebyla.

86 Schůzování a administrativa SÚJV byly nejspíš také důvodem k tomu, že V. Votruba o setrvání na postu náměstka ředitele SÚJV nestál. RNDr. Stanislav Dubnička, DrSc., v osobní vzpomínce na profesora Votrubu uvedl, že „když ho nějaké jednání nebavilo, beze slova se zvedl a odešel“. Stanislav DuBNIČKa, Ohlédnutí za dlouhodobým pracovním pobytem v Laboratoři teoretické fyziky SÚJV, in: E. Těšínská (ed.): Mezi SÚJV a CERN, s. 162.

87 MÚA, fond Zápisy ze schůzí VP ČSAV, k. 12, 51. schůze 6. 11. 1957, bod 8.

88 Archiv SÚJV, fond 3/1/32, ОИЯИ. Стенограмма совещания Коммитета полномочных представителей [КПП] государств-членов ОИЯИ, 25. 11.-26. 11, 1957. s. 35-36.

89 Archiv SÚJV, fond 3/1/34, ОИЯИ. Материалы совещания КПП правительств государств членов ОИЯИ (II сессия). Velvyslanec Vošahlík ve zprávě pro ministra zahraničních věcí o československém postupu na 
Se žádostí o nominace kandidátů na nové náměstky ředitele SÚJV se na vládní zmocněnce členských států ústavu obrátil ředitel Blochincev v červenci 1958; dopis J. Kožešníkovi byl datován 28. července. Zvážení př́ípadných československých kandidátů bylo postoupeno ÚV KSČ. Vedoucí Zahraničního odboru ČSAV Viktor Janata interním sdělením z 6. srpna 1958 informoval J. Kožešníka, že V. Votruba, při náhodném osobním setkání s Janatou, uvedl, ,že kandidatura čs. odborníkủ nepřichází patrně v úvahu, a dále pak, že vhodnou príležitostí k projednání této záležitosti by byla [druhá] ženevská konference, na kterou z ČSR jede akademik Šorm a kterou se za sovětskou stranu zúčastní náčelník Glavatomu Jemeljanov, sovětský vládní zmocněnec pro SÚJV."90 Sovětská strana měla nejspíš zájem o nominaci československého kandidáta (včetně setrvání V. Votruby ve funkci). J. Kožešník však dopisem S. V. Jemeljanovovi ze dne 1. ř́ijna 1958 diplomaticky sdělil názor ČSAV (překlad z ruštiny): „Není pochyb o tom, že by bylo velkou ctí a znamenalo by pro nás také velký užitek, kdyby jako kandidáti byli navrženi čs. představitelé, avšak jiné okolnosti nás nutí kandidaturu odmítnout.

Protože nedávno zemřel profesor Matyáš a v Československu není už jiný profesor, který by se zabýval výchovou mladých fyziků, velmi nutně potřebujeme profesora Votrubu. Proto bychom uvítali Vaše laskavé sdělení, že je možné uvolnit ho z funkce zástupce ředitele. Protože místo Votruby nemáme pro uvedené místo jinou vhodnou osobu, prosíme, aby nebyl nikdo z Československa navrhován jako kandidát.“ Dopis byl adresátem v kopii předán řediteli Blochincevovi. ${ }^{91}$

Na třetím zasedání Výboru vládních zmocněnců, jehož konání bylo posunuto na leden 1959, bylo zvoleno nové ředitelství SÚJV ve složení: ředitel D. I. Blochincev (na další tři roky), náměstci ředitele Wang-Ganchang (ČLR) 92 a Emil Džakov (BLR). Noví náměstci znovuzvoleného ředitele nastoupili do svých funkcí od března t. r. E. Džakov krátce poté, telegramem z 11. března 1959, jménem nového ředitelství SÚJV požádal československého

zasedání Výboru vládních zmocněnců SƯJV v listopadu 1958 komentoval prodloužení funkčního období obou náměstků ředitele SÚJV zhruba takto: V závěru zasedání předneslo ředitelství SÚJV požadavek na prodloužení funkčního období obou náměstků. Jako důvod uvedlo, že členské státy nepřipravily dokonale návrh nových náměstků v patřičné lhůtě, a tudíž není možno v letošním zasedání zplnomocněných zástupců členských států provést volbu. Českoslovenští zástupci na zasedání s tímto zdůvodněním souhlasili a navrhli, aby v budoucnu byl nástupní termín (náměstků) ředitelů posunut na období červenec-srpen, jelikož zpravidla jde o profesory, kteři jsou vázáni na pracoviště vysokých škol členských států. MÚA, fond Řizení a správa pracovišt' ČSAV, k. 194.

90 MÚA, fond Zahraniční a hospodářský odbor (dále ZHO) / Zahraniční odbor (dále ZO) ČSAV, 1953-1959, k. 77. Kopie záznamu připojená ke kopii dopisu J. Kožešníka S. V. Jemeljanovi z 1. 10. 1958.

91 Archiv SÜJV, fond 3/1/84, ОИЯИ, Секретариат. Переписка с полномочным представителем, Посольством в Москве и научными учреждениями Чехословацкой народной республики по воросам финансирования, обьмена кадрами и научных связей, 6. 1. 1958 - 31. 12. 1958. Kopie dopisu J. Kožešníka (zn. VII-10.966/58) postoupená D. I. Blochincevovi.

92 Wang Ganchang (1907-1998), jeden z vedoucích představitelů čínské jaderné a částicové fyziky, později účastník vývoje čínské jaderné bomby. V 30. letech 20. století absolvoval studijní pobyt na univerzitě v Berlíně v Německu, kde vypracoval doktorskou disertaci pod vedením L. Meitnerové. V SÚJV pracoval od roku 1956. Vedl skupinu v Laboratoři vysokých energií, která na základě analýzy snímků z propanové bublinové komory umístěné v magnetickém poli a ozářené svazkem záporných mezonů pí s energií 7-8 GeV na tamním synchrofázotronu objevila záporný anti-sigma hyperon (podivnou částici s dobou života řádově $10^{-10} \mathrm{~s}$, rozpadající se na antineutron a záporný mezon pí). Členem této multinárodní skupiny byl také český fyzik, pracovník Fyzikálního ústavu ČSAV Jiří Vrána, který pracoval v SÚJV od prosince 1959 do prosince 1961 (jeho první dlouhodobý pracovní pobyt v SÚJV). Objev byl ohlášen v roce 1960 a byl oceněn cenou SÚJV za rok 1961. Byl to jeden z prvních objevů učiněných v SÚJV. 
vládního zmocněnce pro SÚJV J. Kožešníka, aby byl V. Votrubovi prodloužen pobyt v Dubně a vízum do konce srpna 1959.93 Žádosti bylo bez námitek vyhověno.

Na Fakultu technické a jaderné fyziky UK profesor Votruba nastoupil znovu k 1. srpnu 1959; od 1. záŕí t.r. byla fakulta organizačně převedena z Univerzity Karlovy na České vysoké učení technické. Na fakultě se V. Votruba poté stal vedoucím katedry teoretické fyziky, která byla zřízena ve školním roce 1959/60 na základě rozdělení dosavadní katedry jaderné fyziky na tři samostatné katedry: jaderné fyziky (vedoucí V. Petržílka), teoretické fyziky (vedoucí V. Votruba) a obecné fyziky (vedoucí J. Beneš). Od 1. ř́ína 1967, v souvislosti s převedením (,vrácením“) fyzikálních kateder z FTJF ČVUT na MFF UK, se profesor Votruba stal opět zaměstnancem MFF UK, kde pak působil do konce profesní kariéry. V roce 1970 byl na částečný úvazek zaměstnán také ve Fyzikálním ústavu ČSAV, aby tam spolupracoval se skupinou teoretické fyziky vysokých energií. V roce 1975 odešel do důchodu, na fakultě byl zaměstnán ještě na částečný úvazek. ${ }^{94}$

Účast V. Votruby na spolupráci se SÚJV pokračovala i po jeho návratu z Dubny a promítala se do jeho profesní kariéry nadále i tím, že na fakultě přebíral pedagogické povinnosti za pracovníky na dlouhodobých pracovních pobytech v SÚJV (např. vedení katedry jaderné fyziky za profesora V. Petržílku v době jeho dlouhodobého pobytu v SÚJV v letech 19591961, přednášky a vedení diplomových prací za I. Úlehlu v době jeho druhého dlouhodobého pobytu v SÚJV v letech 1963-1967). V roce 1961 byl opět jmenován členem Vědecké rady SÚJV; koncem roku 1963 však požádal ze zdravotních důvodů o uvolnění „,z representačních funkcí v SÚJV v Dubně“ .95 Jak již bylo zmíněno, upustil také od zamýšleného dlouhodobého pracovního pobytu v SÚJV jako vědecký pracovník. Nadále však působil (jako člen) v Komisi pro spolupráci se SÚJV, která byla ustanovena v listopadu 1962 jako pomocný orgán československého vládního zmocněnce v SÚJV J. Kožešníka. V roce 1967 (poté co byla část agendy této komise převedena na Fyzikální komisi při Vědeckém kolegiu jaderného výzkumu ČSAV) podrobil vysílání československých odborníků do SÚJV poměrně ostré kritice. Odhodlal se k tomu v souvislosti s návrhem ředitelství SÚJV (resp. náměstka ředitele I. Úlehly) na vyslání asistenta katedry teoretické fyziky FTJF ČVUT Miloše Uhlíře k novému, dvouměsíčnímu pobytu do SÚJV, aby tam dokončil a případně obhájil kandidátskou disertaci. Votruba protestoval tím, že Uhlír pracoval v SÚJV téměř tři roky (pobyt mu byl dvakrát prodloužen) a rok předtím se z Dubny vrátil. V závěru dopisu, v zápalu rozhořčení, dodal: „Nakonec bych při této přiležitosti rád upozornil Vás $i$ akad. Kožešníka na to, že v organizaci vysílání našich lidí do Dubny (a jejich návratů domů)

93 Archiv SÚJV, fond 3/1/124: ОИЯИ, Секретариат. Переписка с полномочным представителем, Посольством в Москве и научными учреждениями Чехословацкой народной республики ..., 5. 1.-31. 12. 1959. Telegram SÚJV, zn. „Иcx. No. 93/29“.

94 Na MFF UK byl V. Votruba převeden jako vedoucí katedry teoretické fyziky II, zatímco I. Úlehla se stal vedoucím katedry teoretické fyziky I. Z vedení katedry (v té době katedra teoretické fyziky I) byl koncem září 1968 odvolán na vlastní žádost, oficiálně ze zdravotních důvodů. V době odchodu V. Votruby do důchodu bylo z kateder teoretické a jaderné fyziky na MFF UK vytvořeno Nukleární centrum v čele s I. Úlehlou. AUK, fond MFF UK, OS Votruba Václav.

95 Přání V. Votruby o jeho uvolnění z Vědecké rady SÚJV bylo tlumočeno (a doporučeno) dopisem J. Kožešníka D. I. Blochincevovi z 12. listopadu 1963. Týmž dopisem byli novými, stálými členy Vědecké rady SÚJV za

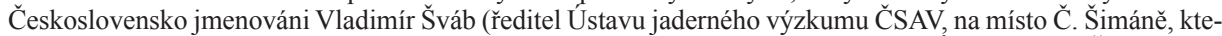
rý v té době již působil v Mezinárodní agentuře pro atomovou energii ve Vídni) a I. Úlehla (FTJF ČVUT). Archiv SÚJV, fond 3/1/289: ОИЯИ, Секретариат. Переписка с полномочным представителем, Посольством в Москве и научными учреждениями ЧССР..., 15. 8.-30. 12. 1963. Dopis J. Kožešníka, zn. 58458/3. 
vládne v poslední době [...] značně nepřehledný zmatek a liboviole. Tato agenda byla svěrena fyzikální komisi VKJV, jíž má přesedat prof. Úlehla; ten však je v Dubně, komise se prakticky nescházi a o záležitosti našich pracovniků v Dubně se asi nikdo z funkcionář̀i nestará. Výsledek je takový, že mnozi naši pracovníci si pobyt v Dubně bez omezení prodlužují (ačkoliv z toho žádný patrný prospěch pro naši vědu nevychází), zatím co jiní tam nemohou (nejsou povoláváni, nebo se značným zpožděním proti plánu, což narušuje práci na našich pracovištích zde), poněvadž Čechoslováků je [v] Dubně stále plno. Bylo by myslím na čase, opět jednou skontrolovat plány pobytů našich lidí v Dubně a uvést skutečnost do souhlasu s nimi. Jsem osobně toho názoru, že pět let pobytu v Dubně je víc než dost, tím spíše, když se tam mnozí z těchto 'stálých'spolupracovníkủ zabývají pracemi povahy povýtce 'remeslné'. Nevím, jak k tomu prijidou naši mladi pracovníci doma, kteři stejnou dobu (pět $i$ více let) pracují na př. na vysoké škole a do Dubny se nedostanou jednak proto, že je doma nemá kdo zastoupit, jednak proto, že už v Dubně pro ně není místo. Domnívám se, že Ti, kdožv Dubně pobývají dlouhá léta z důvodů spíše rodinných nebo proto, že jsou užiteční pro technický provoz laboratoří, by neměli zatěžovat československou kvótu stanovenou pro védecké pracovniky." 96

Kritika vyslovená V. Votrubou tehdy vyvolala na řadě míst nelibost, zdá se však, že přispěla k lepšímu vymezení kompetencí četných orgánů a institucí vstupujících do organizace československé spolupráce se SÚJV. V. Votruba zůstal členem i nové Komise pro spolupráci se SÚJV, která byla jmenována v roce 1971. Účastí na spolupráci se SÚJV však výčet jeho téměř nespočetných vědecko-organizačních funkcí a povinností, které ho čím dál víc odváděly od vlastní vědecké práce, zdaleka nekončí.

Oficiálních uznání za práci vykonanou pro československou fyziku a její reprezentaci na mezinárodním fóru se V. Votrubovi ovšem nedostalo mnoho, nebo na ně musil přinejmenším dlouho čekat. Řád práce, jehož udělení V. Votrubovi bylo navrženo v roce 1964, mu udělen nebyl; až v roce 1982 obdržel vyznamenání Za zásluhy o výstavbu. U př́ležitosti jeho 60. narozenin v roce 1969 mu ČSAV udělila zlatou oborovou plaketu Za zásluhy ve fyzikálních vědách; na jmenování akademikem však čekal do roku 1977 (byt’ návrh na jeho zvolení akademikem byl FTJF ČVUT a Vědeckým kolegiem jaderného výzkumu podán již $\mathrm{V}$ roce 1962). U př́ležitosti 60. narozenin V. Votruby uspořádaly MFF UK a Jednota československých matematiků a fyziků na jeho počest odborný seminár. Koncem roku 1970 byl pak Vědeckou radou MFF UK schválen (a cestou Rektorátu UK) podán k ministerstvu školství návrh na jmenování V. Votruby „zasloužilým vysokoškolským profesorem“; návrh se však nerealizoval, protože ministerstvo školství v červnu 1971 udělování tohoto titulu zrušilo. ${ }^{97}$

96 MÚA, fond ZHO / ZO ČSAV, k. III-166. Dopis V. Votruby vedoucímu Zahraničního odboru ČSAV V. Janatovi z 29. 5. 1967, rukopis na hlavičkovém papíře katedry teoretické fyziky FTJF ČVUT, 3 s. (v citaci je zachováno podtržení slov v dopise). Miloš Uhlír (nar. 1932) byl na dlouhodobém pobytu v SÚJV od ledna 1963 do září 1966. Pracoval v Laboratoři teoretické fyziky u J. A. Smorodinského (podobně jako Pavel Winternitz z Ústavu jaderného výzkumu ČSAV, který pracoval v SÚJV od prosince 1962 do února 1968). K dalšímu, ročnímu pobytu do SÚJV M. Uhlír odjel v březnu 1974. Archiv SÚJV, Osobní složky zahraničních pracovníků SÚJV, Československo, Uhlíř Miloš.

97 Pod zdůvodněním návrhu, datovaným 15. prosince 1970, byl podepsán profesor L. Valenta. V charakteristice pedagogické činnosti V. Votruby mj. uvedl: „Pedagogická práce prof. Votruby byla vždy poznamenána v tom nejlepším smyslu jeho činností vědeckou. Sám jsa u nás a v některých př́padech i ve světě průkopníkem nových vědních oborů a směrů, zaváděl do výuky nové vědní disciplíny - moderní kvantovou teorii, teorii 
Osobnost a dílo profesora V. Votruby připomíná v soudobé české fyzice Cena Václava Votruby. Je udělována od roku 2003 každoročně, ke dni Votrubových narozenin (19. prosince), za nejlepší doktorskou disertační práci v oboru teoretické fyziky obhájenou v předchozích třech školních letech. Soutěž o cenu organizuje Dopplerův ústav Fakulty jaderné a fyzikálně inženýrské ČVUT, finančně cenu sponzoruje Nadační fond pro rozvoj teoretické fyziky. Touto formou památka V. Votruby povzbuzuje a podporuje mladé české teoretické fyziky v jejich vědecké práci. ${ }^{98}$

\section{Závěr}

Účast v SÚJV a spolupráce s tímto ústavem je nedílnou součástí historie česko-slovenské vědy a jejího začlenění do mezinárodní vědecké spolupráce. V příspěvku je zachycen jen velmi krátký, počáteční časový úsek této dnes již téměř 65leté historie, který však nebyl v předchozích pracích zatím pojednán.

SÚJV i spolupracující instituce zúčastněných členských států prošly během této historie zásadními proměnami, co se týče organizační struktury, experimentálního vybavení, výzkumné problematiky a širšího začlenění do mezinárodní vědecké spolupráce. Vědecká činnost ústavu a spolupráce s ním je nicméně i dnes ovlivňována mezinárodně-politickým vývojem a v neposlední řadě také stavem ekonomiky členských států. Věda by však měla národy spojovat.

\section{Grantová podpora:}

Publikace vznikla s podporou na dlouhodobý koncepční rozvoj výzkumné organizace Ústavu pro soudobé dějiny AV ČR, v. v. i., RVO: 68378114.

atomového jádra, teorii elementárních částic a zároveň modernizoval a aktualizoval klasické partie teoretické fysiky, což mělo mnohostranné blahodárné důsledky [...].

Prof. Votruba byl vždy náročný učitel, přednášející i zkoušející na vysoké úrovni, ale přesto vždy otcovsky laskavý, povzbudivě kritický, vždy ochotný poradit i pomoci. Proto vždy kolem sebe stimuloval mimořádně př́znivou tvưrčí atmosféru, v níž vyrostly desítky našich [...] předních teoretických fysiků [...].

[...] Prof. Votruba působil [...] rovněž nějaký čas na Komenského universitě v Bratislavě a někteří jeho tehdejší posluchači spolu s některými Slováky, které přitáhla jeho osobnost př́imo do Prahy, byli základem [...] úspěšné bratislavské skupiny jaderných fysiků a teoretiků z oboru elementárních částic.

Podobně daly přednášky prof. Votruby na budapešt’ské universitě vznik mad'arské škole teorie elementárních částic, z níž vzešli např. [...] fysikové prof. Marx a prof. Román (který prohlásil, že přednášky prof. Votruby byly pro mad'arské fysiky zjevením, jež jim teprve ukázalo, jak se dělá teorie elementárních částic). Podobně tomu bylo i v Sofii, a tak se mezi žáky prof. Votruby čítá např. i bulharský akademik Christo Christov. “Archiv UK, fond MFF UK, OS, Votruba Václav. Návrh na udělení titulu ,zasloužilý vysokoškolský profesor prof. Dr. Václavu Votrubovi, DrSc., členu korespondentu ČSAV, datováno 15. 12. 1970, podepsán prof. Dr. V. Valenta, laureát Státní ceny K. G., vedoucí Katedry teoretické fyziky I na MFF UK.

$98 \mathrm{Viz}<\mathrm{http}: / /$ gemma.ujf.cas.cz/ exner/di/VVposter05.pdf>. 110. výročí narození V. Votruby si na jednodenním semináři (sympoziu) uspořádaném Ústavem částicové a jaderné fyziky MFF UK dne 13. ledna 2020 připomněli někteří z jeho žáků a pokračovatelů. Viz <http://ipnp.cz/cfs/index.php/2019/12/04/ symposium-ke-110-vyroci-narozeni-vaclava-votruby/>. 


\title{
Die Beteiligung der Tschechoslowakei an der Errichtung des Vereinigten Instituts für Kernforschung (Dubna, Russland) und ihre Vertretung in seinem ersten Direktorat
}

\author{
ZUSAMMENFASSUNG
}

Die Tschechoslowakei war einer der ersten Signatarstaaten der Vereinbarung über die Errichtung des Vereinigten Instituts für Kernforschung, die am 26. März 1956 in Moskau unterzeichnet wurde. Zur Teilnahme an der Errichtung dieses Instituts wurde die Tschechoslowakei mit einer „Gedenkaufzeichnung“ vom 18. Januar 1956 eingeladen, die von N.S. Chrustschow unterzeichnet war. Der sowjetische Vorschlag zur Gründung des Instituts war die Antwort auf formlose Gespräche, die auf der Ersten internationalen Konferenz für die friedliche Nutzung der Atomenergie in Genf im August 1955 zwischen Physikern aus West- und Osteuropa über eine internationale Zusammenarbeit in der Hochenergiephysik stattfanden. Das Institut sollte für die volksdemokratischen Länder eine Paralleleinrichtung zum Europäischen Laboratorium für Kernforschung (CERN) werden. Die Sowjetunion bot die Errichtung des Instituts auf der Grundlage zweier Einrichtungen der sowjetischen Akademie der Wissenschaften im Gebiet von Moskau an: des Instituts für Kernprobleme mit dem Synchro-Zyklotron $560 \mathrm{MeV}$ (Megaelektronenvolt) und des Elektrophysikalischen Laboratoriums mit dem Bau des Teilchenbeschleunigers Synchrophasotron $10 \mathrm{GeV}$ (Gigaelektronenvolt).

An der Beratung zur Institutsgründung vom 20.-26. März 1956 in Moskau nahm eine achtköpfige tschechoslowakische Delegation unter Leitung des Energieministers F. Vlasák teil, der bevollmächtigt war, für die Tschechoslowakei die Abschlussvereinbarung zu unterzeichnen. Namens der tschechoslowakischen Delegation trat in der Beratung das Delegationsmitglied J. Baier auf (amtierender stellvertretender Vorsitzender des tschechoslowakischen Regierungsausschusses für Forschung und friedliche Nutzung der Atomenergie), der auf den möglichen Beitrag tschechoslowakischer Physiker, Ingenieure und der Maschinenbauindustrie bei der Forschung und dem Aufbau des Instituts aufmerksam machte (Bau von Teilchenbeschleunigern und Kernanlagen).

Am Ende der Moskauer Beratungen wurde das erste Institutsdirektorat gewählt: der sowjetische Physiker D. I. Blochinzew und seine beiden wissenschaftlichen Stellvertreter: der polnische Physiker M. Danysz und der tschechoslowakische Physiker V. Votruba. Dem Direktorat wurde auferlegt, binnen drei Monaten einen Entwurf der Institutsstatuten zu erarbeiten.

Václav Votruba (1909-1990), korrespondierendes Mitglied der Tschechoslowakischen Akademie der Wissenschaften (ČSAV), Professor für theoretische Physik an der Karlsuniversität und Doktor der physikalisch-mathematischen Wissenschaften, war im Ausland ein bekannter und respektierter theoretischer Physiker. Im Studienjahr 1947/48 arbeitete er bei G. Wentzel und W. Pauli in Zürich. Wissenschaftliche Kontakte pflegte er auch zu sowjetischen theoretischen Physikern (bspw. zu V. A. Fok). Er publizierte Arbeiten zur Relativitätstheorie, Quantenelektrodynamik und zur Theorie der Elementarteilchen.

Der Vorschlag, den tschechoslowakischen Physiker als einen der zwei wissenschaftlichen Stellvertreter des Institutsdirektors zu ernennen, kam bei der Moskauer Beratung vom Leiter der sowjetischen Delegation A. W. Toptschijew. Die tschechoslowakische Delegation konsultierte diesen Vorschlag telefonisch mit dem stellvertretenden Ministerpräsidenten und Vorsitzenden des Regierungsausschusses für Forschung und friedliche Nutzung der Atomenergie, V. Kopecký in Prag. Von den beiden erwogenen Kandidaten: C. Šimáně (Elektroingenieur und Direktor des tschechoslovakischen Instituts für Kernphysik, Mitglied der Delegation der Moskauer Beratung) und V. Votruba, wurde Letzterer genehmigt, der seine Ernennung annahm (er befand sich damals dienstlich in Sofia). Aufgrund des Berichts der Delegation über die Teilnahme an der Moskauer Beratung wurde im August 1956 die Tschechoslowakische Akademie der Wissenschaften mit der Agenda der Zusammenarbeit mit dem Vereinigten Institut für Kernforschung in Dubna betraut; der Regierungsausschuss für Forschung und friedliche Nutzung der Atomenergie wurde im Juni 1956 aufgelöst. In den ersten wissenschaftlichen Beirat des Instituts wurden für die Tschechoslowakei V. Petržílka (korrespondierendes Mitglied der ČSAV, Professor und erster Dekan der Fakultät für technische und Kernphysik der Karlsuniversität), Č. Šimáně und F. Kováŕ (ab 1955 in Moskau tschechoslowakischer Botschaftsrat für Fragen der Kernenergie) delegiert; V. Votruba wurde in seiner Funktion als stellvertretender Institutsdirektor Mitglied des wissenschaftlichen Beirats. Zum Regierungsbevollmächtigten für die im 
September 1956 stattfindende konstituierende Sitzung des Vereinigten Instituts für Kernforschung, auf der die Institutsstatuten verabschiedet wurden, ernannte man J. Kožešník (korrespondierendes Mitglied und Stellvertreter des Hauptsekretärs der ČSAV, ausgebildeter Maschinenbauingenieur und Spezialist für angewandte Mathematik und Mechanik; die Funktion des Regierungsbevollmächtigten für das Institut hatte er bis Ende 1980 inne).

V. Votruba war als wissenschaftlicher Stellvertreter des Kernforschungsinstitutsdirektors in den Jahren 19561959 tätig (die zweijährige Amtszeit war ihm und auch M. Danysz um ein Jahr verlängert worden). In dieser Funktion war er mit der Agenda der ausländischen Institutsmitarbeiter betraut. Die ersten tschechoslowakischen Fachleute, die für einen langfristigen Arbeitsaufenthalt in das Institut entsandt wurden, waren die theoretischen Physiker I. Úlehla (wissenschaftlicher Mitarbeiter des Instituts für Kernphysik) und Jan Fischer (wissenschaftlicher Aspirant des Physikalischen Instituts der ČSAV). 1956 kamen weitere 13 tschechoslowakische Wissenschaftler und Fachleute zu einem langfristigen Arbeitsaufenthalt in das Vereinigte Institut für Kernforschung (Physiker, Chemiker, Ingenieure und Techniker). Während seiner Tätigkeit im Vereinigten Institut nahm V. Votruba auch an drei internationalen Spitzenkonferenzen über Hochenergiephysik teil (bekannt geworden unter der historischen Bezeichnung Rochesterkonferenzen): der siebenten Konferenz 1957 in Rochester (USA), der achten 1958 in Genf und an der neunten 1959 in Kiew.

Im Januar 1957 besuchte eine tschechoslowakische Regierungs- und Parteidelegation mit Staatspräsident A. Zápotocký das Vereinigte Institut für Kernforschung in Dubna. Gemeinsam mit dem Institutsdirektor und weiteren führenden Institutsmitarbeitern begrüßte V. Votruba die Delegation und begleitete sie bei der Institutsbesichtigung. Er nutzte die Gelegenheit der Begegnung mit Zápotocký, um ihm gegenüber seinem Ersuchen um Freilassung seines ehemaligen Aspiranten und Mitarbeiter M. Lokajíček zu wiederholen, dass er bereits im Januar 1955 an den Präsidenten gerichtet hatte. M Lokajíček (1923-2019) war 1954 verhaftet und wegen seiner Beteiligung an dem katholischen Verein „Rodina“ zu sieben Jahren Freiheitsentzug verurteilt worden. Auf Anweisung des Staatspräsidenten wurde nach seinem Besuch in Moskau der Fall erneut untersucht und M. Lokajíček im Juni 1957 aus der Haft entlassen. Als wissenschaftlicher Mitarbeiter im Physikalischen Institut der Tschechoslowakischen Akademie der Wissenschaften wurde er jedoch erst ab 1. Januar 1969 eingestellt, nachdem er rehabilitiert worden war und 1968 einen einjährigen Arbeitsaufenthalt im Hochenergielaboratorium des Vereinigten Instituts für Kernforschung in Dubna absolviert hatte.

(Deutsche Übersetzung Wolf B. Oerter)

Emilie Těšinská,

Ústav pro soudobé dějiny $A V \check{C} R, v$, v. i.

tesinska@cesnet.cz 


\section{Obrazová príloha}

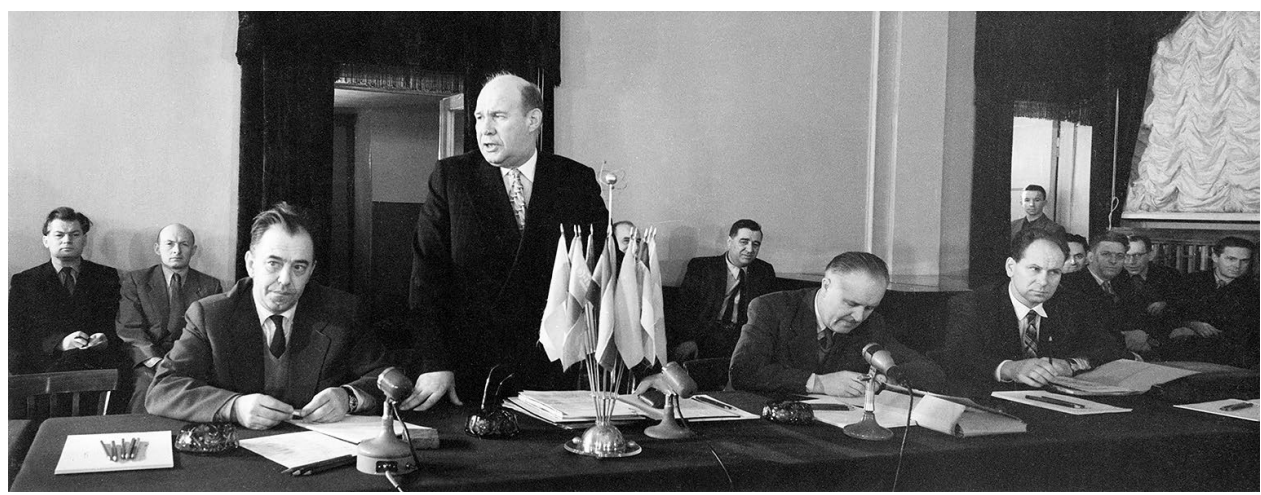

Obr. 1 Představitelé prvního ředitelství SúJV: zleva M. Danysz, D. I. Blochincev a V. Votruba (fotografie ze zasedání Vědecké rady SÚJV v lednu 1959) [Zdroj: Elektronický fotoarchiv SÚJV Dubna <http://photo.jinr.ru/>, foto P. I. Zol'nikov]

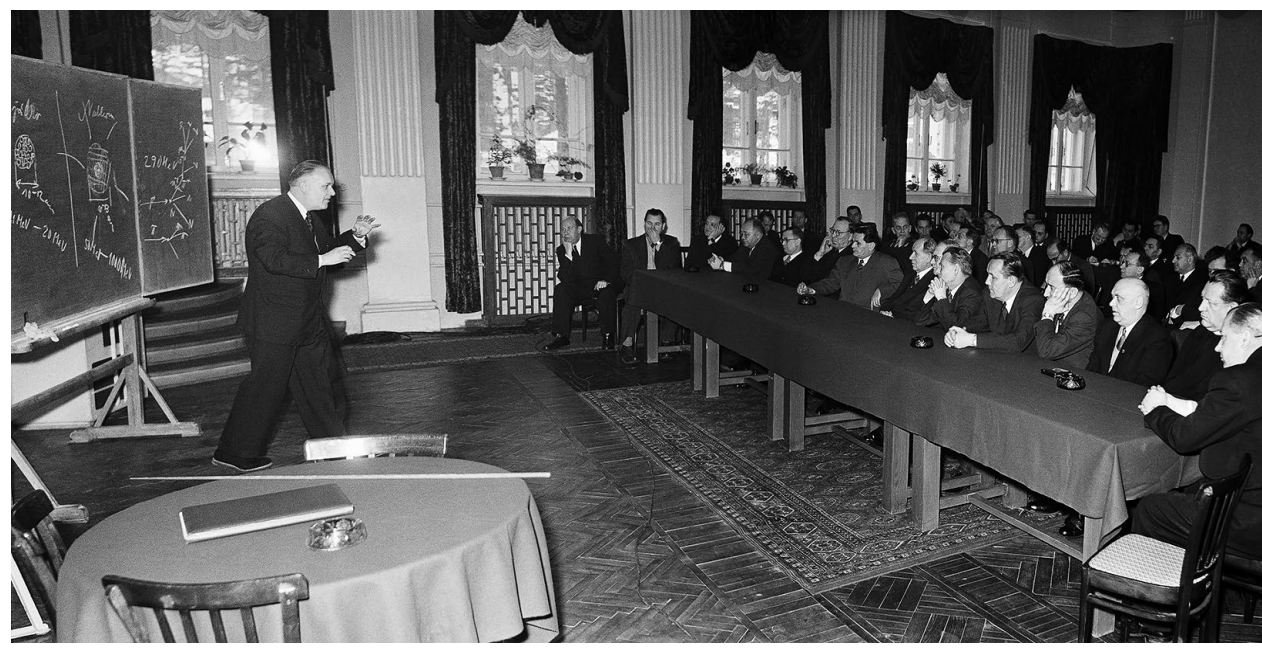

Obr. 2 Přijetí československé vládní a stranické delegace v SÚJV v lednu 1957. Vědecký náměstek ředitele ústavu $\mathrm{V}$. Votruba informuje členy delegace o pracích ústavu v oboru fyziky vysokých energií. V první řadě naslouchají mj. V. Kopecký, A. Zápotocký a A. Novotný, na kraji u okna ředitel ústavu D. I. Blochincev [Zdroj: Fotobanka ČTK, foto Jiří Rubič] 


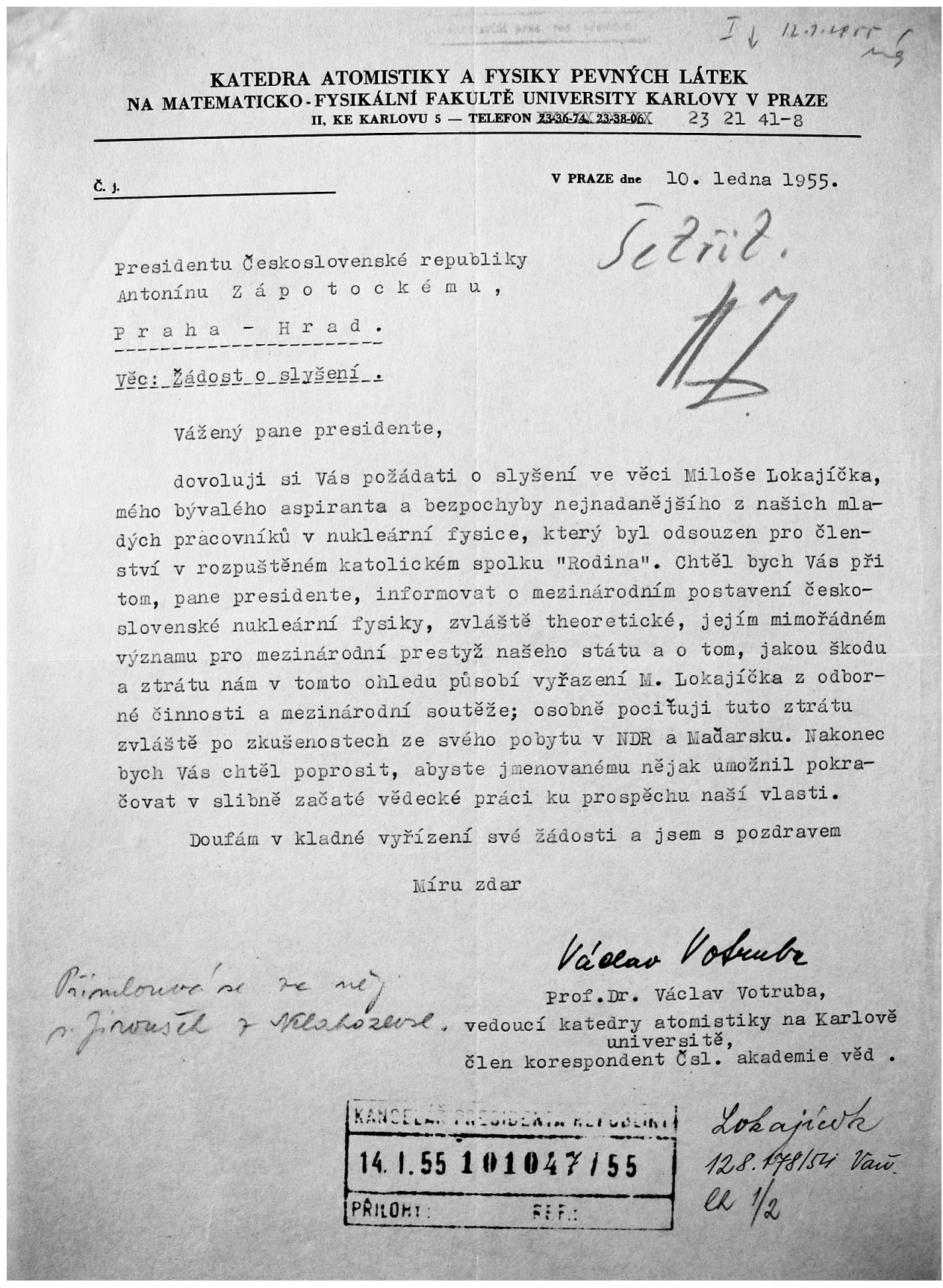

Obr. 3 Dopis V. Votruby prezidentu A. Zápotockému z 10. ledna 1955 se žádostí o slyšení ve věci $M$. Lokajíčka. Na dopise $A$. Zápotockým červeně pripsán pokyn $k$ prošetření věci [Zdroj: AKPR, fond Protokol T 1945-1963, spis č. 101.047/55] 